No. X.-COLEOPTERA; HYDROPHILID $\nRightarrow$, HISTERID $Æ$.

By Hugh Sсотt, M.A. (Cantab.), F.L.S., F.E.S., Curator in Entomology in the University of Cambridge.

\title{
(Plate 14.)
}

Read 5th June, 1913.

THIs paper is a report on the Hydrophilidæ and Histeridæ of the islands in the western Indian Ocean visited by the Percy Sladen Trust Expedition in 1905 and 1908-9 : that is, the Seychelles, the Farquhar Group, Aldabra and the neighbouring islands, \&c. It is the result of a study of the collection formed by this Expedition, but species previously recorded from these islands but not collected by the Expedition are also included in their proper systematic position, so that the paper may provide a complete enumeration of the Hydrophilidæ and Histeridæ known from these groups of islands. 23 species of Hydrophilidæ and 16 of Histeridæ are here enumerated, while previously only 6 Hydrophilidæ and 8 Histeridæ had been recorded. 14 new species and 3 new genera are described.

As regards general considerations of affinities, distribution, \&c., the two families are considered separately, a brief general account being prefixed to the systematic account of each on pages 194 and 222 respectively*.

Types. A first set of all the material, including the types of all new species and genera, will be given to the British Museum. A second set will be kept in the Cambridge University Museum.

Localities. Under each species is given a locality-list including the fullest possible data as to where and when it was found. The dates " 1908 " or "1908--9" standing alone (i.e., not followed by a collector's name) after any data, always indicate that the specimens were collected by myself, or by some of those who helped me while I was in the Seychelles. Similarly " 1905 " standing alone indicates that the material was obtained by the earlier Percy Sladen Trust Expedition (that is, the Expedition of H.M.S. "Sealark"). In all other cases the collector's name is placed in brackets after the data. When a species is found outside the area of the Expedition, a brief summary of its external distribution is given at the end of the locality-list.

Literature. In the literature-references the abbreviation "Alluaud, Liste Coléopt." stands for Alluaud's "Liste des Insectes Coléoptères de la Région Malgache" (vol. xxi. of Grandidier's “Histoire Physique, Naturelle et Politique de Madagascar,” 1900). I have frequently had to refer to papers by Régimbart, Ann. Soc. ent. France, vol. lxxii. 1903, and vol. lxxv. 1906. The Histeridæ collected in the Seychelles by Alluaud in 1892 were reported on by J. Schmidt in Bull. Soc. ent. France, 1893, p. 99. Certain

* Almost entirely the same system is followed as in my paper on the Lamellicornia and Adephaga, in vol. xv. of these Transactions, 1912, p. 215. 
other matters connected with the literature are mentioned in the writer's paper in vol. $\mathrm{xv}$. of these Transactions, 1912, p. 215.

It is a pleasure to express my thanks for the generous help which I have received from several entomologists in dealing with these families of Coleoptera. Monsieur Charles Alluaud has very greatly assisted me by lending a number of specimens for purposes of comparison. I am specially indebted to Monsieur P. Lesne for his kindness in lending me valuable specimens from the Paris Museum, and for comparing specimens which I have sent to him with species in the Paris Collections. Monsieur A. d'Orchymont has examined a number of the Hydrophilidæ; I am indebted to him for several determinations and for allowing me to make absolutely unrestricted use of his very full and accurate manuscript-notes on them. Lastly I have to thank $\mathrm{Mr}$ George Lewis for determining certain of the Histeridæ and for the gift of several valuable specimens.

\section{Hydrophilidø.}

23 species, representing 12 genera, are here enumerated from the islands visited by the Expedition. Only 6 species had previously been recorded. Of the 17 additions, 9 are described as new to science, and it has been necessary to erect 3 new genera to receive certain minute forms among them. 22 species are actually represented in the collection made by the Expedition : the remaining one (Colostoma punctulatum) has been recorded as found by a previous collector.

The distribution of the species, so far as known, is shown in the following table:

\begin{tabular}{|c|c|c|c|c|}
\hline \multirow{2}{*}{$\begin{array}{l}\text { Before the names of the species: } \\
\text { * indicates that the species is new to science, } \\
+ \text { indicates that the species is recorded from } \\
\text { these islands for the first time, but not } \\
\text { new to science. }\end{array}$} & \multicolumn{3}{|c|}{$\begin{array}{l}\text { Distribution among the islands } \\
\text { visited by the Expedition }\end{array}$} & \multirow{2}{*}{ External Distribution } \\
\hline & $\begin{array}{l}\text { Seychelles } \\
\text { Group }\end{array}$ & $\begin{array}{l}\text { Coetivy } \\
\text { Island }\end{array}$ & Aldabra & \\
\hline 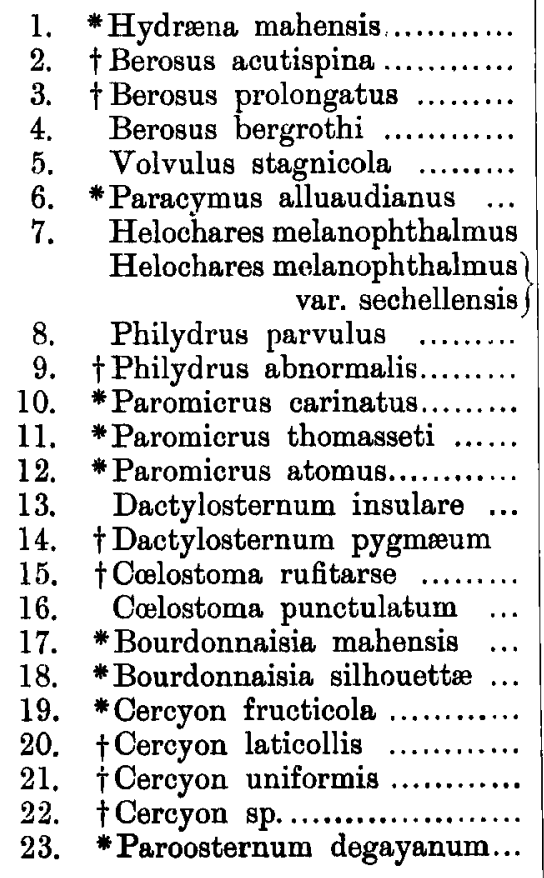 & 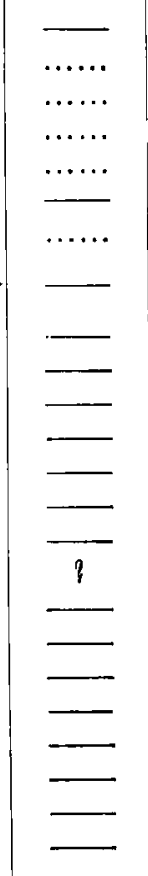 & $\begin{array}{l}\ldots \ldots \\
\ldots \ldots \\
\ldots \ldots \\
\ldots \ldots \\
\ldots \ldots \\
\ldots \ldots\end{array}$ & $\overline{-}$ & $\begin{array}{l}\text { Madagascar } \\
\text { Madagascar } \\
\text { Madagascar } \\
\text { Trop. Africa } \\
\text { Madagascar, Africa, Trop. Asia, S. Europe } \\
\text { Madagascar, Africa, India, \&c. } \\
\text { Madagascar, British E. Africa, Ceylon, [? Sumatra] }\end{array}$ \\
\hline
\end{tabular}


It is seen that no Hydrophilidæ were collected in the Chagos, Amirantes, Farquhar, or Cargados Carajos groups of coral-islands, and none have ever to my knowledge been recorded from those groups.

The table shows that 18 species were found in the Seychelles: 15 of these were found only in that archipelago (and, in the case of two of them, in the outlying coral-island of Coetivy, close to the South); 3 species were found also in Aldabra. 9 species in all were found in Aldabra, that is the three (all widely distributed species) which occur also in the Seychelles, and six others. In discussing affinities it will be best to consider the Seychelles and Aldabra separately.

Seychelles. Of the 18 species, 13 are terrestrial and 5 are aquatic. Among the terrestrial forms there is almost certainly an endemic element in the fauna, consisting of the completely wingless new genus Bourdonnaisia, represented by two distinct species each confined to a single island: the extreme restriction of their habitat to the very summits of the highest peaks, in the heart of the endemic forests, is dealt with on p. 215. In affinities this genus appears to be isolated.

The second new genus, Paromicrus, is fully winged, and represented by three minute species, not confined to single islands nor so restricted in habitat as Bourdonnaisia, but still almost entirely confined to the endemic forests, where they are amongst the most abundant beetles under the bark of decaying wood (see p. 207). This genus is allied to the Hawaiian Omicrus : at first I thought it was endemic to the Seychelles, but M. d'Urchymont has informed me (in litt.) that he has two other species, one from Engano, a small island south-west of Sumatra, the other from the Abor country (Assam). Neither of these is identical with any of the Seychelles species, specimens of all of which were submitted to M. d'Orchymont: so the Seychelles species may perhaps be confined to those islands, though the genus is not.

The third new genus, Paroosternum (also fully winged), is represented by only two specimens: it is allied to a genus known from Central America and Japan. Such affinities may seem remarkable, but until Hydrophilidæ so minute as these have been more thoroughly collected throughout the world, it would be unwise to attach too much weight to them.

Among the remaining land-inhabiting Hydrophilidæ it is doubtful whether there is any endemic element at all. Dactylosternum insulare (found also in Aldabra) is very wide-spread: Dactylosternum pygmoum is known from Mauritius: Colostoma punctulatum is wide-spread African and Madagascan: Cercyon fructicola may perhaps be allied to a form known from Mauritius : Cercyon laticollis is known from Madagascar; Cercyon uniformis from Ceylon and India. These species are all found in rotting fruit - very often in the fruit of imported trees-at various elevations (see locality-lists), and, with the possible exception of Cercyon fructicola, are probably immigrant or imported species.

Turning now to the aquatic forms: the writer has several times mentioned * that the very numerous mountain-streams of the Seychelles have only a small aquatic insect-

* Trans. Linn. Soc. London, Ser. 2, Zool., xiv. 1910, p. 28 : ibid. xv. 1912, pp. 242, 258. 
fauna, and that only one species of water-beetle (the Dytiscid Copelatus gardineri) was found in them in any numbers. This is fully borne out by the aquatic Hydrophilidæ: only two specimens (one of Philydrus abnormalis and one of Philydrus parvulus var.) were found at any considerable elevation, both of them in the Mare aux Cochons plateau (Silhouette), over 1000 feet above sea-level. All the other aquatic Hydrophilidæ which I collected in the Seychelles were found quite near sea-level, either in the coastal swamps or estuary at Anse Royale, Mahé, or in a pond near the beach in Félicité Island. Hydrona mahensis, though described here as a new species, is very closely allied to or possibly only a form of a Madagascar species : Paracymus alluaudianus (found in Coetivy), also described as new, is allied to a species found in Madagascar and in East Africa and Eritrea: Helochares melanophthalmus var. sechellensis is a local form of a very wide-spread species: Philydrus parvulus is very widely distributed in the warmer regions of the Old World, and occurred in Coetivy and Aldabra as well as in the Seychelles: Philydrus abnormalis occurs in Madagascar, British East Africa, Seychelles (Silhouette), Ceylon, and possibly also in Sumatra.

Aldabra. 7 of the 9 species are aquatic and 2 terrestrial. The three species which occur also in the Seychelles (Philydrus parvulus, Philydrus abnormalis, Dactylosternum insulare) are all very wide-spread, as stated above: a fourth species Helochares melanophthalmus (represented in the Seychelles by a special form) is also very wide-spread. Of the 5 remaining species, the 3 species of Berosus are all known from Madagascar (one of them, Berosus acutispina, having very close allies in Africa and apparently also in

Tonkin); Colostoma rufitarse is Madagascan and African: the Volvulus is somewhat doubtfully referred to an African species. The Aldabran Hydrophilid fauna therefore contains Madagascan and African elements, and an element consisting of species very widely spread in the warmer parts of the Old World. Its general nature thus appears similar to that of the Lamellicorn and Adephagous fauna of Aldabra (see vol. xv. of these Transactions, 1912, pp. 220 and 242).

Reduction of wings. As mentioned above, the new genus Bourdonnaisia is completely apterous (see p. 214). No other case of reduction of the alar organs was found in the Hydrophilidæ. [An interesting case was found in the Histeridæ, see pp. 224, 230.]

\section{Hydrænini.}

Hydrana, Kugelann.

Subgenus Hydrana, s. str., Ganglbauer, Käf. Mitteleur., iv. 1, 1904, p. 197.

1. Hydrona mahensis, sp. nov.

Minuta, sat nitida, capite nigricante, pronoto medio infuscato marginibus sat late ferrugineo-testaceis, elytris fusco-testaceis, antennis palpisque pedibusque testaceis : capite sat dense punctato: palpis valde elongatis, articulo 2 fere æque longo ac $3+4$, extrorsum arcuato, gracillimo, apice parum incrassato: prothorace transverso, ante medium parum angustato, angulis anticis rotundatis, pone medium fortius angustato et lateribus leviter 
sinuatis, angulis posticis argutis fere rectis, margino antico æque lato ac basi, marginibus lateralibus tenuiter crenulatis, disco fortiter dense punctato, utrinque ad latera, antice fortius, impresso: elytris sat curtis, in parte mediâ quam prothorace latioribus, apice separatim rotundatis et suturâ dente minutâ instructâ, marginibus lateralibus explanatis, arcuatis ; sat fortiter dense seriatim punctatis, intervallis angustis (æque latis ac seriebus), planis, nullo modo elevatis. Long. corp. circa $1 \frac{1}{4} \mathrm{~mm}$.

General colour brownish-testaceous: head darker, almost black; pronotum with a roughly rectangular transverse median area darkly infuscate, and the margins rather widely ferrugino-testaceous; elytra brownish-testaceous ; antennæ, palps, legs and feet testaceous. Head: præ-frons finely punctured, nearly smooth in the middle, post-frons more strongly punctured: fronto-antennal suture nearly straight: labrum large and bilobed: maxillary palpi very long, joint 2 very long, about as long as 3 and 4 together, curved outwards, very slender from the base to nearly $\frac{3}{4}$ of its length, slightly swollen in its apical portion; joint 3 slender at the base, in its distal half about as swollen as the apex of 2 ; joint 4 about $1 \frac{1}{2}$ times as long as 3 , more swollen, convex on the inner side and nearly straight outwardly: antennæ with joint 2 as broad as the apex of 1 , joint 3 very minute, almost invisible, 4 produced inwardly into a finely-pointed process, club 5-jointed and pubescent. Pronotum transverse, having its greatest breadth at a point about the middle, with the sides slightly narrowed in front of this point to the anterior angles, which are rounded; with the sides behind the widest point more strongly narrowed, and sinuate in such a way that the posterior angles are definite and nearly right angles: width of anterior and posterior margins about equal, that of the anterior greater than that of the head and eyes: lateral margins finely crenulate: disc closely and strongly punctate, much more strongly than the head; with an impression on either side quite near the lateral margin, broader and more marked in front, gradually narrowing towards the posterior angles. Scutellum visible but minute. Elytra about $2 \frac{1}{2}$ times as long as the pronotum, with lateral margins curving outwards from the base, so that a little behind the shoulder the elytra become considerably broader than the pronotum even at its broadest point: lateral margins explanate, very finely crenulate near the shoulder and near the apex, the crenulations much less close than on the thorax: apices separately rounded, with a minute tooth present at the apex of the sutural margin : each elytron bears about 15 or 16 series of punctures, 9 of which lie between the humeral callus and the suture: the punctures are about the same size as those on the thorax, in each series separated from one another by about their own diameter; while the intervals between the series are about the same width as the series themselves and not at all raised or convex. From each puncture rises a minute pale procumbent hair, not easily visible: some such hairs are also visible on the head and thorax. The nature of the punctuation is such that its seriate arrangement is not always very apparent.

Beneath, the body is covered with pale pubescence. There are no raised ridges on the metasternum; but in the one specimen examined the pubescence is thinner on two longitudinal areas, one on either side of the middle line of the metasternum. In this specimen also the 5th abdominal segment and part of the 6th appeared nearly bare 
of pubescence, but I could not quite determine whether this was natural or due to abrasion; lack of material prevented my determining the sex of the specimens.

This species is very closely allied to the Madagascan Hydroena marginicollis Régimbart (Ann. Soc. ent. France, lxxii. 1903, p. 51), and may possibly prove to be only a variety or small local race of that species. I have been able to study a typical specimen of marginicollis through the kindness of $\mathrm{M}$. Alluaud: it is considerably larger; has the prothorax slightly more narrowed in front of the middle, and a little more narrowed and with sides more strongly sinuate behind the middle; the palps are formed in the same way, but the apex of the long 2 nd joint, and the terminal joint, appear slightly less incrassate than in mahensis. Also marginicollis has the elytra a little less strongly separately rounded at the apex, and the angle between them (at the end of the suture) a little less deep: but the form of the elytra at the apex might depend on the sex, which smallness and fragility of material have prevented my determining either in mahensis or marginicollis. [Beneath marginicollis resembles mahensis: the apical part of the 5th segment of the specimen before me is nearly bare of pubescence, the basal part of the 6th is widely bare and smooth, while the apical part of the 6th has scanty pubescence.]

Loc. Seychelles. Mahé : marshes on coastal plain at Anse aux Pins and Anse Royale, 19-21. I. 1909, 2 specimens.

\section{Hydrophilini.}

Berosus, Leach.

Subgenus Enoplurus, Hope, Col. Man., ii. 1838, p. 128.

2. Berosus (Enoplurus) acutispina, Fairmaire.

Berosus acutispina Fairmaire, Ann. Soc. ent. France (sér. 4), viii. 1868, p. 196 ; Régimbart, op. cit., lxxii. 1903, p. 36 ; Alluaud, Liste Coléopt., p. 228.

2 f, 4 of from Aldabra. There is much variation even in this small series, specimens varying in length from $4 \frac{1}{2}-6 \frac{1}{4} \mathrm{~mm}$. The colour is also variable; the dark marblings on the posterior part of the elytra vary, being reduced in some specimens while in others they form a double oblique dark band with a much paler portion between its two parts*.

The determination was confirmed by Monsieur Lesne, who states that he can find no differences between specimens submitted to him and Fairmaire's type. Monsieur d'Orchymont, to whom I had previously submitted specimens, considered them to be the East African Berosus gracilispina Régimbart (Ann. Soc. ent. France, lxxv. 1906, p. 264), which may possibly be the same as Erichson's Berosus cuspidatus from

* Monsieur d'Orchymont called my attention to variation in the manner in which the striæ meet one another at the apex of the elytron: he informs me that in the subgenus Enoplurus they usually meet in the following pairs : 1 and 2, 3 and 8,4 and 7, 5 and 6,9 and 10. But in $1 \delta$ and $2 q$ of the Aldabra B. acutispina, the pairs are: 1 and 2,3 and 4,5 and 6,7 and 8,9 and 10. Monsieur d'Orchymont has observed this variation also in specimens of $B$. (Enoplurus) indicus Motsch. 
Angola. Monsieur d'Orchymont compared the Aldabra specimens with a $f$ from Tonkin determined as Berosus acutispina Fairmaire: he found certain differences in punctuation and form, especially in the form of the tarsal claws, which are much shorter in the Aldabra specimens, and in the front tarsus more arcuate, than in the Tonkin specimen. In view of Monsieur Lesne's determination it appears possible that the Tonkin specimen is not of the same species as the true acutispina described by Fairmaire from Madagascar.

I am unable to say if the Madagascan acutispina Fairmaire is the same as the African gracilispina Régimbart, but at least they seem to be extremely closely allied.

Loc. Aldabra: from “Wilson's Well," Takamaka, X.-XI. 1908 (Fryer). Madagascar.

3. Berosus (Enoplurus) prolongatus, Fairmaire.

Berosus prolongatus Fairmaire, Ann. Soc. ent. France (sér. 4), viii. 1868, p. 196 ; Régimbart, op. cit., lxxii. 1903, p. 36 ; Alluaud, Liste Coléopt., p. 229.

3 f, 1 o from Aldabra: compared with a specimen (from Madagascar) kindly lent from the Paris Museum by Monsieur Lesne, who informs me that it appears quite similar to Fairmaire's type. The Aldabra specimens are very much paler in colour, being almost entirely yellow: only the posterior part of the head, the extreme apex of the terminal joint of the maxillary and labial palps, the two longitudinal patches on the pronotum, the striæ* and punctures on the interstices of the elytra, and some vague markings on the anterior and posterior parts of the elytra, are darker. In three of the Aldabra specimens the prothorax is a little shorter in proportion to its width than in the specimens lent from Paris.

The punctuation on the præ-frons is finer and considerably less dense than on the post-frons, where it is coarser and closer, especially behind (at the extreme anterior margin of the præ-frons it is very fine and rather close). The intra-ocular systematic punctures form a line of confluent punctures nearly parallel to the margin of the eye and larger than the general punctuation. The scutellum is an elongated triangle with sharp apex, with a rather wide border raised a little above its general surface, and a line of punctures along either side against the border, the median part of the surface being impunctate. The setiferous punctures on the elytra are well marked but few, being most numerous on the 3rd, 4th, 5th and 11th interstices. The one $q$ has the apex of its elytra a little more narrowly and deeply truncate-emarginate than the $3 \hat{\delta}$.

Beneath, the prosternum and anterior coxæ are pale yellowish; remainder of the underside dark, almost black, the middle coxæ and mesosternum being slightly more dilute, very dark reddish-black : basal part of the femora scarcely infuscate in the anterior pair, almost black in the middle and posterior pairs; remainder of the femora, tibiæ and tarsi reddish-yellow. Under-surface of body, coxæ and basal portions of femora dull,

* In all 4 specimens of $B$. (Enoplurus) prolongatus the manner in which the striæ meet one another at the apex of the elytron is almost that which d'Orchymont informs me is normal in this subgenus: cf. footnote on B. acutispina, p. 198. 
very minutely and closely rugose-punctate, covered with very fine, short, pale pubescence, except the mesosternum.

Loc. Aldabra: from "Wilson's Well," Takamaka, X.-XI. 1908 (Fryer). Madagascar.

Subgenus Berosus, s. str., Ganglbauer, Käf. Mitteleur., iv. 1, p. 220.

\section{Berosus bergrothi, Régimbart.}

Berosus bergrothi Régimbart, Bull. Soc. ent. France, 1900, p. 51, and Ann. Soc. ent. France, lxxii. 1903, p. 40 ; Alluaud, Liste Coléopt., p. 229 ; Kolbe, Abh. Senckenb. Ges., xxvi. 1902 , p. 574.

A large series of about 260 specimens, agreeing well with Régimbart's description. But there are certain variations. Régimbart stated that the dark metallic patch on the disc of the prothorax is not divided by a pale median line: in a number of the specimens, however, it is narrowly divided, completely or almost completely. Some specimens have the anterior margin of the prothorax dark in the middle part, behind the head; but this dark colour is not united to the front of the median patch, which never reaches either the front or hind margins.

Three specimens exhibit more striking variation. In one of them, a $\hat{\delta}$, the dark thoracic patch is reduced to two very small patches, completely separated and situated in the posterior part of the disc. In the two others, $q$, 9 , the dark mark is entirely absent, the prothorax being uniformly pale: these also have the dark elytral marks much reduced, in one specimen practically absent. They show no signs of immaturity, the head being entirely dark bronze with metallic reflections, as in all other specimens.

Régimbart also stated that the thoracic punctuation is not interrupted by a smooth median space : this is quite true in many specimens, but in some a slight indication of a median longitudinal smooth line can be seen with a high power.

Judging by Régimbart's descriptions (l.c.), this species must be closely allied to Berosus villosulus Rég. (Madagascar) and B. vitticollis Boh. (S. Africa and Madagascar).

Loc. Aldabra: Takamaka, X.-XI. 1908 (Fryer); 1895 (Voeltzkow). Madagascar.

\section{Volvulus, Brulle**}

\section{Volvulus stagnicola (Mulsant).}

Brachygaster stagnicola Mulsant, Ann. Soc. Linn. Lyon (sér. 2), i. 1853, p. 385, and Opusc. Ent., ii. 1853, p. 177 ; Alluaud, Liste Coléopt., p. 229.

Volvulus stagnicola Régimbart, Ann. Soc. ent. France, lxxv. 1906, p. 267.

Brachygaster denticulata Régimbart (nec Muls.), Ann. Soc. ent. France, lxxii. 1903, p. 41.

Volvulus cupreus Régimbart, Bull. Soc. ent. France, 1900, p. 51; Alluaud, l.c.; Kolbe, Abh. Senckenb. Ges., xxvi. 1902, p. 574.

* The name Regimbartia is proposed for this genus, and the synonymy dealt with, by Zaitzev in his Cat. Hydrophil., Horæ Soc. Ent. Ross., xxxviii. 1908, p. 362. 
Régimbart first described specimens from Aldabra as cupreus: in 1903 (l.c.) he stated that he considered this a synonym of denticulata: and again in 1906 (l.c.) he considered that this was a mistake, and that the Aldabra specimens were referable not to denticulata, but to stagnicola. The name cupreus then became a synonym of stagnicola, and as such it is given by Zaitzev in his Catalogue (1908, p. 362).

In the absence of types wherewith to compare it, I refer a single $\hat{\alpha}$, which agrees with Régimbart's descriptions, to this species. Length, including the extended head, $5 \mathrm{~mm}$. ; palps reddish, legs black, slightly ferruginous : head fairly closely punctured : thorax less closely punctured in the middle, nearly as closely as the head at the sides: elytra with the two striæ nearest the suture effaced towards the base over about $\frac{1}{5}$ of their length, the 3rd and 4th faint towards the base, the 5th reaching almost to the base, the 6th and 7 th abbreviated a little before the base (the 6 th ending in the region of the callus, in which region its punctures become widely spaced out, and the 7 th ending a trifle further from the base than the $6 \mathrm{th}$ ), and the $8 \mathrm{th}, 9 \mathrm{th}$ and $10 \mathrm{th}$ (i.e. the outermost) reaching practically to the base: striæ much deeper behind, crenulate-punctate : the punctures of the intervals much finer than those of the striæ, and the hairs which they bear extremely short and fine and hard to see (possibly the specimen is worn; but the pubescence is less conspicuous than in several specimens determined as $V$. ceneus Brullé which I have before me).

Loc. Aldabra: Takamaka, 1908, 1 f (Fryer); 1895 (Voeltzkow). Volvulus stagnicola is widely spread in Tropical Africa (see Régimbart, 1906, l.c.: V. denticulatus is known from Madagascar).

Paracymus, Thomson.

Subgenus Paracymus, s. str.

6. Paracymus alluaudianus, sp. nov.

Supra nigro-æneus, prothoracis lateribus et elytrorum apicibus obscure rufescentibus, antennis palpisque rufo-ferrugineis, antennarum clavis atque articuli $4^{\mathrm{i}}$ palporum apice infuscatis; subtus capite, meso- et metasternis, abdomineque nigris, prosterno pedibusque rufo-ferrugineis : capite pronoto elytrisque dense fortiter punctatis: mesosterno pone dentem anteriorem carinulâ longitudinali instructo; femoribus mediis pubescentiâ haud ultra medium attingente. Long. corp. $2 \mathrm{~mm}$.

Shining, with a strong brassy lustre; antennæ, palps and legs rather dark reddish; beneath, the head, meso- and metasterna and abdomen are black, while the prosternum is reddish. The species is characterised by the strong and dense punctuation of the upper surface : on the head the punctures are very small near the anterior margin, larger behind, the largest being on either side near the eye ; on the pronotum the punctures are a little finer and further apart than those on the elytra: on the elytra they are densest and largest, often not separated by much more than their own diameter, and especially close in the scutellar region. The elytra have no trace of seriate punctuation: the sutural stria is well marked, abbreviated in front. Under high power the elytral punctures appear simple and circular. 
Paracymus alluaudianus is closely allied to the Madagascan and East African Paracymus chalceus Régimbart (Ann. Soc. ent. France, lxxii. 1903, p. 32), a cotype of which I have been able to study through the kindness of M. Lesne. Its upper and under sides are coloured similarly to those of alluaudianus, but it is a trifle larger, and at once distinguished by its much finer and less dense punctuation. This difference is very noticeable when the two are viewed side by side. In chalceus (as in alluaudianus) the elytral punctures are simple and circular.

Among the European species, aneus Germar is separated from scutellaris Rosenh. and punctillatus Rey by having an elevated longitudinal lamina on the mesosternum behind the tooth and transverse' crest, and by having the pubescence on the middle femora scarcely reaching to the middle: scutellaris and punctillatus having no longitudinal elevated lamina on the mesosternum, and the pubescence reaching beyond the middle of the middle femora (Ganglbauer, Käf. Mitteleur., iv. 1, p. 241). In these respects alluaudianus and chalceus approach oeneus Germ., having a small but distinct elevated lamina, and the pubescence scarcely reaching to, and certainly not beyond, the middle of the middle femora.

Paracymus evanescens (Sharp) from Ceylon and India (of which a typical specimen from the British Museum is before me) agrees with alluaudianus and chalceus in possessing a small elevated mesosternal lamina and in having the pubescence not reaching beyond the middle of the middle femora. But it is much smaller than either of those species (the specimen before me measures only $1 \frac{1}{2} \mathrm{~mm}$.) and quite distinct from them in punctuation (see below) : also the underside (in this specimen at any rate) is, with the exception of the head, much lighter-coloured, being yellowish.

Paracymus minor Régimbart (Ann. Soc. ent. France, lxxii. 1903, p. 33) has a minute longitudinal elevation on the mesosternum, but in it the pubescence extends beyond the middle, to about $\frac{3}{4}$ the length of the middle femora: in this latter respect it differs from alluaudianus, chalceus, evanescens, \&c., and approaches scutellaris Rosenh. \&c. But though minor differs thus from evanescens, yet in their upper surfaces these two species are rather closely alike. They are the same size, and in both of them the elytral punctures, instead of being simple and circular, have the form of minute figures-of- 8 , as though each puncture were formed by the coalescence of two*: in this point therefore they differ widely from alluaudianus and chalceus. In evanescens the cephalic and thoracic punctures are larger and subobsolete, in minor finer and clearer cut. Paracymus evanescens and minor are therefore quite distinct from one another, and from alluaudianus or chalceus: minor is known from Madagascar and perhaps occurs also in British East Africa; I have been able to study the type of the species through the kindness of M. Alluaud.

Paracymus alluaudianus is named in honour of Monsieur Charles Alluaud.

Loc. Seychelles: Mahé; marshes on coastal plain at Anse Royale, I. 1909, 66 specimens. Coetivy; 1905, 2 specimens.

* Note, this only applies to the elytral punctures: cephalic and thoracic punctures are simple. 


\section{HeLochares, Mulsant.}

\section{Helochares melanophthalmus, Mulsant.}

Helochares melanophthalmus Mulsant, Hist. nat. Col. France, Palpicornes, 1844, p. 137 ; Alluaud, Liste Coléopt., p. 231 ; Régimbart, Ann. Soc. ent. France, Ixxii. 1903, p. 27 ; Kolbe, Abh. Senckenb. Ges., xxvi. 1902, p. 574 ; id., Mitt. Zool. Mus. Berlin, v. 1910 , p. 24.

Helochares nigrifrons Régimbart, Bull. Soc. ent. France, 1900, p. 50.

Régimbart first determined $(1900$, l.c.) specimens from Aldabra as $H$. nigrifrons Brancsik, stating that he was inclined to consider it as simply a form of melanophthalmus : in his later paper $(1903$, l.c.) he still refers the Aldabra specimens to it, but treats it as var. nigrifrons of melanophthalmus; Kolbe states $(1902$, l.c.) that nigrifrons Brancsik cannot be separated from melanophthalmus. But Zaitzev in his Catalogue (p. 381, 1908) treats the two as distinct species. I have been unable to investigate the matter and follow Régimbart and Kolbe in referring the form found in Aldabra to melanophthalmus.

Loc. Aldabra: Takamaka, 1908, 12 specimens (Fryer): 1895 (Voeltzkow). Madagascar, Africa, S. Europe.

Helochares melanophthalmus Mulsant var. sechellensis, Régimbart.

Var. sechellensis Régimbart, Ann. Soc. ent. France, lxxii. 1903, p. 27 ; Kolbe, Mitt. Zool. Mus. Berlin, v. 1910, p. 24.

This form is clearly distinguished from that found in Aldabra by its finer and less dense punctuation, and consequently more shining appearance, and by its generally larger size. The specimens before me agree well with Régimbart's description.

Loc. Seychelles. Félicité : from a pond in a plantation at Grande Anse, XII. 1908, 7 specimens. Mahé : marshes on coastal plain at Anse Royale, I. 1909, 5 specimens ; 1896 (Brauer). La Digue: 1892 (Alluaud).

\section{Philydrus, Solier.}

Subgenus Methydrus, Rey; Ganglbauer, Käf. Mitteleur., iv. 1, p. 243.

8. Philydrus (Methydrus) parvulus, Reiche.

Philydrus parvulus Reiche, Ann. Soc. ent. France, sér. 3, iv. 1856, p. 359 ; Régimbart, Bull. Soc. ent. France, 1900, p. 50 ; id., Ann. Soc. ent. France, lxxii. 1903, p. 31 ; Alluaud, Liste Coléopt., p. 231 ; Kolbe, Abh. Senckenb. Ges., xxvi. 1902, p. 574 ; id., Mitt. Zool. Mus. Berlin, v. 1910, p. 24.

Régimbart's remarks (l.c.) about the extreme variability of this species in colour, size, \&c., are amply borne out by the large series of over 140 specimens before me. Some specimens are small and very pale, others much larger and dark, and there are various intermediate gradations. This variation occurs, to a large extent at any rate, independently of sex. The triangular yellow marks on the head in front of the eyes appear to be constant in both sexes. 
In both sexes there is a blunt tooth at the base of both claws of all the feet. In the $\hat{\sigma}$ the claws of the anterior tarsi are much more sharply bent, and the teeth more prominent, than in the $q$. In the claws of the middle and posterior tarsi $I$ have not been able to make out any appreciable difference in the two sexes, neither does there appear to be any appreciable difference between the outer and inner claws in either sex. This does not agree with Kuwert's statement (Verh. naturf. Ver. Brünn, xxviii. 1889, p. 56), "§̊ Aeussere Krallen sämmtlicher Füsse mit einem langen scharfen Zahn." The exact form of the claws is not easy to determine, even with a high power.

Both sexes have a clear-cut, rather deep, rounded emargination, set with a series of yellowish setæ, in the middle of the posterior margin of the 5 th ventral segment. The whole segment is pubescent, and the pubescence is sometimes rather denser at the hind margin immediately on either side of the emargination: but the setæ fringing the emargination are of quite a different nature, being much stouter at the base and tapering to the apex, set in a single regular series close together. Kuwert (l.c.) stated of this species : "f Fünftes Segment mit einem kleinen gelbhaarigen Grübchen am Ende." But in the series before me the emargination is present in both $\delta$ and $q$, and apparently of the same form in both sexes. The segment is sometimes a little impressed near the emargination, and when the setæe are stuck together they render its nature less apparent: this might possibly account for Kuwert's use of the word "Grübchen" instead of "Ausschnitt."

Loc. Seychelles: Mahé ; coastal plain at Anse Royale, I. 1909 ; 1896 (Brauer) : Félicité, from a pond at Grande Anse (sea-level), XII. 1908. Coetivy, 1905. Aldabra: Takamaka, 1908 (Fryer); 1895 (Voeltzkow). Madagascar, Tropical Africa, Egypt, Syria, India.

Philydrus parvulus, Reiche, var.?

A single $q$ has the entire præ-frons yellow, in contrast to the black posterior part of the head. It appears as though the triangular yellow patches have extended across the head and united : in the other specimens they seem to be constant, though Régimbart states (l.c.) that they are variable in this species. The specimen also has the 3rd joint of the maxillary palpi a trifle shorter in proportion to the 2 nd, and the thoracic and elytral punctuation slightly finer and less dense, than in other females of the series.

In having the præ-frontal region entirely yellow and the punctuation finer, this specimen resembles Philydrus fragilis Sharp (Ceylon: Trans. Ent. Soc. London, 1890, p. 350). But it agrees with the other specimens of parvulus in size and general form and in the stronger punctuation of the head. Philydrus fragilis is larger than the largest of the series of Philydrus parvulus, and slightly more oval in outline, owing to the sidemargins of the elytra being more curved : its punctuation, especially on head and thorax, is finer and more obsolete, even than that of the var. of parvulus under consideration. The specimen of fragilis before me has on either side of the head, in the region of the intra-ocular systematic punctures, a slight impression which I have not seen in parvulus : its yellow præ-frons is obscured in the middle, whereas that of the Philydrus parvulus var. from Silhouette is entirely yellow. 
Loc. Seychelles. Silhouette: Mare aux Cochons plateau, over 1000 feet, IX. 1908. 'It is the only specimen from Silhouette, and the only one from the Seychelles mountains, all the other Seychelles specimens having been found almost at sea-level.

Subgenus Philydrus*, s. str., Horn; Ganglbauer, Käf. Mitteleur., iv. 1, p. 243.

9. Philydrus abnormalis, Sharp.

Philydrus abnormalis Sharp, Trans. Ent. Soc. London, 1890, p. 351.

Enochrus abnormicollis $\uparrow$ Zaitzev, Cat. Hydrophilidæ, Horæ Soc. Ent. Ross., xxxviii. 1908 , p. 385.

Philydrus mollis Régimbart, Ann. Soc. ent. France, lxxii. 1903, p. 32 ; id., op. cit., lxxv. 1906, p. 263.

(?) Philydrus rubricollis Régimbart, t.c., p. 58.

Four specimens : determined by comparison with a typical specimen of abnormalis in the British Museum (Mr George Lewis' Collection), with which they closely agree. By the kindness of Monsieur Lesne I have also been able to compare them with a cotype of Régimbart's mollis : this is immature (Régimbart stated that almost all the specimens on which his description was based were immature), and consequently appears very different in some ways, being light yellow instead of the normal dark blackish-brown; but a close examination has convinced me that it is identical with Philydrus abnormalis. Also Monsieur d'Orchymont has informed me that the Seychelles specimen submitted to him is identical with one from Tamatave in his collection. Philydrus abnormalis and Philydrus mollis are therefore the same: possibly the Sumatran Philydrus rubricollis Régimbart is also identical, as its description agrees and Régimbart stated that it might be so. Two other species, known from both Indo-China and Sumatra, appear to be closely allied, having the palps very greatly elongated in the same manner, \&c.; they are Philydrus ferrugatus Régimbart and $P$. nigritulus Régimbart, described in the same paper with rubricallis (t.c., pp. 57, 58).

The four specimens are dark brownish-black, with the labrum and the sides of the head in front of the eyes, the four margins of the pronotum narrowly, and the outer margins of the elytra more broadly, dark reddish; antennæ and the greatlyelongated palpi testaceous. Beneath, dark reddish-brown or pitchy-reddish, the abdominal segments blackish with posterior margins dark reddish: surface dull, the metasternum, femora, and abdominal segments covered with very short, fine, pale pubescence: legs dark reddish-brown, femora somewhat infuscate, tarsi paler, testaceous. On the disc of the elytra two series of larger, setiferous punctures can be distinguished, the outer less complete and more irregular than the inner. The anterior margin of the præ-frons is widely, very shallowly, and subangularly, emarginate.

* Zaitzev proposes the name Lumetus for this subgenus in his Catalogue, l.c.

$\dagger$ The name abnormalis is changed into abnormicollis in Zaitzev's Catalogue: this must be by error, as no reason is given, and abnormalis is not preoccupied in the genus. Zaitzev's reference to Sharp's description is otherwise correct. 
Two structural points appear to have escaped notice hitherto :

(I) The mentum, which is transverse, is deeply excavated in the middle in front: the front margin runs obliquely forwards on either side of the excavation: most of the surface (including the excavated part) is strongly rugose, near the posterior angles it is punctate.

(II) The last ventral segment is almost truncate or perceptibly sinuate behind, and in the middle the hind margin is set with a series of minute setæ rather like the teeth of a comb. They are pale in colour, and quite different from the ordinary pubescence of the segment, being much stouter than the ordinary hairs: the setæ in the middle of the series are shorter than those on either side. Insufficiency of material has prevented my determining whether this structure is confined to one sex, or present and of the same form in both sexes; in Philydrus parvulus setæ of a somewhat similar kind are present in both sexes: see p. 204.

Loc. Aldabra: Takamaka, 1908, 3 specimens (Fryer). Seychelles: Silhouette; from a small pool on the plateau, Mare aux Cochons, over 1000 feet, 25. IX. 1908, 1 specimen. Madagascar, British East Africa, Ceylon, [Sumatra?].

Paromicros, gen. nov. (Plate 14, figs. 1-11).

Antennæ 9-articulatæ, articulis 7-9 clavam compactam formantibus. Labrum haud occultum, transversum. Palpi maxillares articulo $2^{\circ}$ sat incrassato, $3^{\circ}$ quam $2^{\circ}$ breviore, $4^{\circ}$ quam $3^{\circ}$ longiore. Mentum trapezoidale, transversum. Elytra seriebus regularibus punctorum munita. Alæ perfectæ. Prosternum breve, antice in medio elevatum sed haud carinatum. Mesosternum in medio elevatum; parte elevatâ haud carinatâ sed aream marginatam, antice in apicem ventraliter directum productam, formante. Metasternum in medio leviter elevatum, antice inter coxas intermedias productum, haud carinatum, cum mesosterno suturâ transversâ conjunctum. Segmentum abdominis basale in medio longitudinaliter carinatum. Tarsi omnes 5-articulati, articulis $1--4$ brevibus, subæqualibus, articulo 5 longiore.

Genus Omicro affine, sed valde differt in formâ mesosterni; metasterno in medio minus elevato, articulo $2^{\circ}$ palporum maxillarium minus incrassato.

Form oblong-oval (in Paromicrus atomus slightly narrowed behind), moderately convex, the upper surface bearing an extremely fine and scanty pubescence which is not easily visible without a compound microscope. Head short and broad, depressed in front of the eyes, which project subangularly, truncate in front. Antennce (Pl. 14, fig. 2) 9-jointed in both sexes, the 1st joint elongate, 2nd short and broad, 3rd narrow, joints 4-6 transverse and very short, 7-9 forming a compact club. Labrum (Pl. 14, figs. 3, 4) exposed, very short and transverse; its front margin either shallowly sinuate ( $P$. carinatus and $P$. thomasseti) or angularly emarginate $(P$. atomus) on either side, and bearing a group of ciliæ in the middle, and one on either side outside the sinuation. Mandibles (Pl. 14, fig. 5) rather delicate, without apical or other teeth. Maxilla (Pl. 14, fig. 6) with the lobes membranous, the upper one with several regular rows of setæ hooked at their extremities, the lower one with a minute ciliate process on its upper margin near 
the outer angle, and with the outer margin shortly ciliate above: maxillary palpi with the 2nd joint incrassate distally, 3rd joint shorter than 2nd, 4th joint longer than 3rd. Labium (Pl. 14, fig. 7) with the mentum trapezoidal, transverse and slightly impressed in the middle in front; lobes of the ligula projecting and densely ciliate; palpi short and minute, densely ciliate, the basal joint very short, 3rd joint narrower and a little shorter than the 2 nd.

Elytra with regular series of punctures, without striæ except in $P$. atomus, in which a very fine sutural stria is present. Wings present and fully developed in all the three species, over $1 \frac{1}{2}$ times as long as the elytron. Prosternum short, elevated in the middle in front, the elevated portion sloping somewhat on either side, but not carinate: behind the coxw it does not end in a free process. Mesosternum (Pl. 14, figs. 9-11) elevated in the middle; the elevated portion does not form a narrow keeled lamina, but a margined area varying in form and shape in the different species, but always ending anteriorly in a ventrally-projecting point (see Pl. 14, fig. 9, $a$ and $b$ ) : behind, the mesosternum is divided from the metasternum between the coxæ by a transverse suture. Metasternum elevated in the middle, not sharply or suddenly, projecting forward between the coxæ but not keeled. Abdomen composed of 5 ventral segments, the basal one with a median longitudinal carina. Tarsi (Pl. 14, fig. 8) 5-jointed, joints $1-4$ short and subequal in length, joint 5 considerably longer; the short basal joint is not always easily visible.

Type of the genus: Paromicrus carinatus, sp. nov.

Paromicrus is akin to Omicrus Sharp (Trans. Ent. Soc. London, 1879, pp. 81, 82), from the Hawaiian Islands. I have a specimen of the type of that genus, Omicrus brevipes Sharp (l.c.) before me. The great difference between it and Paromicrus lies in the form of the mesosternum; in Omicrus this forms in the middle a sharply-elevated, narrow, linear lamina, continuous with the elevated and forward-projecting part of the metasternum, whereas in Paromicrus it forms a broad margined area differing in form in the different species, and produced into a ventrally-directed point in front. The middle part of the metasternum is much more sharply and strongly elevated in Omicrus. The maxillary palps of Omicrus are formed (as stated by Dr Sharp, l.c.) much as in Megasternum: their 2nd joint is much more incrassate than in Paromicrus, and the terminal joint appears narrower and more tapering towards the apex. Moreover, Omicrus brevipes is completely different in appearance from any of the species of Paromicrus: its shape is not the same, its elytra are not explanate at the sides and have not the series of punctures, \&c.

Three species of this genus were found: none of them is confined to one island, but I found each of them in Mahé, Silhouette and Praslin, and $P$. atomus also in Félicité. $P$. carinatus and $P$. thomasseti were obtained only in the high endemic-forest districts, but $P$. atomus was also found in some places in the lower country. They are found either under the bark of decaying wood, or (in the case of $P$. carinatus and $P$. thomasseti) between the leaf-bases of growing precinctive palms*. They are sometimes very abundant, and on some occasions I obtained a large number of specimens from a single

* See vol. xiv. (1910) of these Transactions, p. 24 ; and cf. vol. xv. (1912) pp. 225, 226. 
decaying log or a single growing palm-tree. Two other species of the genus are known, from Engano (an island near Sumatra) and from the Abor country (see p. 195). The three Seychelles species may be distinguished as follows:-

Larger : each elytron with three raised longitudinal carinæ : sides of thorax explanate ................................................. P. carinatus.

Larger: elytra without carinæ, but with intervals between series of punctures convex; sides of thorax explanate in front.......2. P. thomasseti.

Smaller: elytra without carinæ and with interstices flat; sides of thorax not explanate 3. P. atomus.

10. Paromicrus carinatus, sp. nov. (Plate 14, figs. 1-3,5-9).

Oblongo-ovalis, prothoracis elytrorumque marginibus sat valde explanatis, subopacus, fusco-ferrugineus vel fuscus, marginibus pedibusque dilutioribus, palpis antennisque testaceis, his clavâ interdum infuscatâ; prothorace minutissime reticulato, disco postice utrinque parum elevato-tumido; elytris suturâ atque carinis tribus in disco obtusis elevatis, sat grosse haud profunde seriatim punctatis, seriebus duabus in intervallo utroque inter carinas, prope medium basis elevatione tumidâ obtusâ; mesosterni parte elevatâ aream fere oblongam, superficie parum concavâ, formante. Long. corp. ca. $1 \frac{1}{4} \mathrm{~mm}$.

Form oblong-oval, sometimes very slightly narrowed behind, with the sides of the thorax and elytra explanate. Colour more or less dark brownish ferruginous with margins and legs lighter, antennæ and palpi testaceous. Subopaque, this being due to extremely fine reticulation or rugulosity of the surface; with a compound microscope the head is seen to be closely covered with a sculpture of extremely fine transverse lines, and the prothorax with a reticulation consisting of excessively fine punctures and scratches, while the surface of the elytra is very minutely rugulose-reticulate: a few fine hairs can also be seen on the thorax and elytra. The disc of the thorax is slightly elevated or tumid on either side behind, which causes the sloping sides of the disc to appear vaguely impressed on either side in front of this elevated portion. The elytra are without any sutural stria; they have regular series of rather large but very shallow punctures; the space between the first series and the suture is strongly elevated, and the $3 \mathrm{rd}, 5 \mathrm{th}$, and 7 th interstices are also elevated into blunt but perfectly well-marked carinæ running the length of the elytron nearly to its posterior extremity: thus the dorsal part of the elytron has blunt longitudinal carinæ, and two series of punctures in each interval between them; the intermediate interstices are only very slightly convex; in the sloping lateral part, the alternate interstices are not elevated into carinæ; both the carinæ and the other interstices bear lines of very minute punctures; at the base of each elytron, a little outside the middle and in the region of the outermost carina, is an obtuse but quite distinct boss, or elevation. The elevated part of the mesosternum ( $\mathrm{Pl}$. 14, fig. 9) forms an area longer than broad, with sides nearly parallel and strongly margined, its surface slightly concave and with only a minute trace of a median elevation behind. The undersurface of the body is beautifully reticulated, and the femora, the elevated central part of the metasternum, and the abdominal segments, bear very sparse short hairs. 
The series consists of nearly 300 specimens ; some of the smallest are only $1 \mathrm{~mm}$. long; some immature specimens are yellow.

This species is at once distinguished by the remarkable sculpture of the elytra and their basal boss, by the conspicuously explanate side-margins of thorax and elytra, and the form of the mesosternum. The plan of the elytral sculpture-alternate interstices being raised into carinæ-recalls that of Oxyomus palmarum (see vol. xv. of these Transactions, p. 224, and Pl. 12, fig. 1).

Loc. Seychelles. Silhouette: high forest near Mont Pot-à-eau, circa 1500 feet, VIII. 1908 ; many specimens, including one recorded as found between leaf-bases of a Roscheria palm, and one as found in a decaying fallen "Bois Rouge" (Wormia). Mahé: high forest of Morne Blanc and Morne Pilot, 1000-2000 feet (some specimens found between leaf-bases of a growing Stevensonia palm); high forest between Trois Frères and Morne Seychellois, and slopes of Morne Seychellois, 1500-2000 feet; Mare aux Cochons district, 1500-2000 feet; forest above Cascade Estate, 800-2000 feet. Praslin : Coco-de-Mer forest in Vallée de Mai, Côtes d'Or Estate, XI. 1908.

\section{Paromicrus thomasseti, sp. nov. (Plate 14, fig. 10).}

Oblongo-ovalis, nitidus, fusco-ferrugineus, marginibus suturâque pedibusque dilutioribus; capite prothoraceque dense minutissime punctulatis, hoc lateribus solum ad angulos anticos explanatis; elytris lateribus minus late explanatis, haud carinatis, sat fortiter seriatim punctatis, intervallo quoque parum convexo et lineâ irregulari punctulorum minutorum munito, elevatione basali obsoletâ; mesosterni parte elevatâ aream latiorem, polygonam vel fere circularem, superficie in medio postice longitudinaliter carinato-elevatâ, formante. Long. corp. ca. $1 \frac{1}{4} \mathrm{~mm}$.

Head very finely and closely punctulate, with a rather vague transverse impression, more or less developed, on either side between the eyes. Thor ax with the lateral margins explanate only in front, and even there not broadly explanate, the disc very closely and finely punctulate, with a slight impression on either side of the middle at the base. Elytra with the side-margins explanate, more broadly behind, and a little less conspicuously so than in $P$. carinatus; with regular series of fairly strong punctures, the interstices being slightly convex and bearing each an irregular line of minute punctures: carinæ are quite absent, the alternate interstices being not more elevated than the rest, and a basal boss corresponding to that in $P$. carinatus is either absent altogether, or only a very slight trace of an elevation is visible. The elevated part of the mesosternum (Pl. 14, fig. 10) is very differently formed from that in $P$. carinatus; it is broader in proportion to its length, polygonal, with the sides convergent behind, and with a sharplyelevated median longitudinal carination on the posterior part of its surface. The scanty hairs on the under-surface appear a little longer than in $P$. carinatus, and the intermediate and posterior tarsi are shorter and stouter than in that species.

Distinguished by its shiny surface, by the sides of the thorax being explanate only in front, by the absence of carinæ on the elytra, and by the different form of the mesosternum. 
The series contains about 170 specimens, the majority of which were found between the leaf-bases of various wild palms.

This species is dedicated to $\mathrm{Mr} \mathrm{H}$. P. Thomasset.

Loc. Seychelles. Silhouette: high forest near Mont Pot-à-eau, circa 1500 feet, a number of the specimens having been found between the leaf-bases of two growing palms (a Stevensonia and another, genus not recorded) on the 2nd and 7th of August 1908 ; forest above Mare aux Cochons, including 26 specimens from leaf-bases of one growing Stevensonia and six from those of another, both on Sept. 22nd. Mahé : forest above Cascade Estate, including over 40 specimens from leaf-bases of a single growing Stevensonia; summit of Mount Sebert, over 2000 feet, 11 specimens from leaf-bases of a growing Stevensonia; from near Morne Blanc, some from leaf-bases of a growing Verschaffeltia palm, others from those of a Stevensonia. Praslin : Coco-de-Mer forest in the Vallée de Mai, Côtes d'Or Estate, 11 of the specimens being from between the leafbases of a growing $f$ Lodoicea palm ("Coco-de-Mer").

12. Paromicrus atomus, sp. nov. (Plate 14, figs. 4 and 11).

Minutus, oblongo-ovalis, postice parum angustatus, nitidus, ferrugineus plus minusve infuscatus; capite prothoraceque dense minutissime punctulatis, hoc lateribus haud explanatis ; elytris striâ suturali tenui, antice obsoletâ, munitis, lateribus postice anguste explanatis, fortiter seriatim punctatis, seriebus parum impressis, intervallis fere planis, intervallo quoque lineâ punctulorum minutorum munito; mesosterni parte elevatì aream rhomboidalem, elevatione transversâ tenui instructam, formante. Long. corp. ca. $1 \mathrm{~mm}$.

Head and prothorax appearing smooth, but under a compound microscope seen to be closely covered with an exceedingly fine, semi-reticulate punctuation. Prothorax practically not explanate at, all at the sides, only under a high power is a very slight trace of flattening of the margin visible in front. Elytra with the side-margins only very narrowly explanate, with a very fine sutural stria, often difficult to see and becoming obsolete in front, with regular series of large strong punctures, the series slightly impressed, the interstices almost flat and each bearing a series of minute punctures. Elevated part of the mesosternum (Pl. 14, fig. 11) forming a roughly diamond-shaped four-sided area, which bears a fine transverse elevated ridge, and behind this (towards its posterior extremity) a median elevation. The elevation of the median part of the metasternum is more marked than in the preceding species.

The labrum (Pl. 14, fig. 4) is differently formed from that of $P$. carinatus or $P$. thomasseti, the sinuations of its anterior margin being deeper and more angular.

The distinguishing features are the smaller size, shiny surface, the side-margins of the thorax not being explanate and those of the elytra only very slightly so, the interstices on the elytra being nearly flat, and the form of the mesosternum.

The series consists of over 100 specimens. It is not confined to the high mountainforests, as some specimens were found in lower country. I have no record of finding any specimen between the leaf-bases of a palm.

Loc. Seychelles. Silhouette: high forest near Mont Pot-à-eau, circa 1500 feet; forest near Mare aux Cochons plateau, many specimens, including some recorded as found 
under bark of a partly-decayed Draccena stem; low coconut-planted country near the coast at Pointe Étienne. Mahé : forest of Morne Blanc; high forest between Trois Frères and Morne Seychellois, 1500 -2000 feet; forest above Cascade Estate; Mare aux Cochons district, 1500-2000 feet; Long Island. Praslin: Coco-de-Mer forest in Vallée de Mai, Côtes d'Or Estate. Félicité : from forest.

\section{Sphæridiini.}

Dactylosternum, Wollaston.

\section{Dactylosternum insulare (Castelnau).}

Dactylosternum insulare Castelnau, Hist. Nat. Col., ii. 1840, p. 59.

Dactylosternum insulare Alluaud, Liste Coléopt., p. 233 ; Régimbart, Ann. Soc. ent. France, lxxii. 1903, p. 46 ; Kolbe, Mitt. Zool. Mus. Berlin, v. 1910, p. 24.

A series of about 150 specimens of this subcosmopolitan species.

Loc. Seychelles. Silhouette : from near Mont Pot-à-eau, ca. 1500 feet, VIII. 1908 ; Mare aux Cochons and forest above, 1908. Mahé: from near Morne Blanc, ca. 5001000 feet, 1908; high forest between Trois Frères and Morne Seychellois, 15002000 feet, 1908; Cascade Estate, ca. 1000 feet, 1908-9; Long Island, VII. 1908 ; 1906 (Thomasset) ; 1905; 1896 (Brauer). Praslin : Côtes d'Or Estate, 1908; 1905. Also found in the Seychelles by Alluaud (1892). Very common in rotting fruit, especially oranges and "jak," where it is often found together with Cercyon uniformis, Cercyon fructicola, certain Nitidulidæ (especially Haptoncus ocularis Fairm. and Brachypeplus arqualis Walker), and certain Staphylinidæ. As can be seen from the above list, it is found in many localities, from cultivated country near sea-level to the endemic mountain-forests.

Aldabra: Picard Island (Fryer).

Described from Mauritius; distributed over all the warmer regions of the Old World.

\section{Dactylosternum pygmoum, Régimbart.}

Dactylosternum pygmaum Régimbart, Ann. Soc. ent. France, lxxii. 1903, p. 45.

16 specimens. This determination was first made for me by Monsieur d'Orchymont, and has since been confirmed by Monsieur Lesne, who found no difference between the specimen submitted to him and Régimbart's type. The specimens agree with Régimbart's description: he lays stress on the prothorax being perceptibly wider at the base than the elytra, but this is not a very perceptible character; in contracted specimens the posterior angles of the thorax slightly overlap the shoulders of the elytra, and in extended specimens the thorax does sometimes appear a trifle wider at the base.

This species is entirely distinct from even the smallest specimens of Dactylosternum insulare not only by its much shorter and more convex form, but by a number of other characters also. The punctuation is very much finer and much less dense, and quite different in nature; in $D$. insulare it consists of fairly strong simple punctures, but in pygmaum each puncture is very fine and has two minute fine scratches or striolæ radiating 
from it, usually at an obtuse angle to one another; on the head the punctuation is closer, and the striolæ almost form a network, but on the thorax and elytra (especially) they are much more separated; the striolæ lie in various directions, but usually more or less transverse. In D. pygmaum the front margin of the eye is only so shallowly emarginate that the emargination is hard to discern, not deeply and sharply emarginate as in $D$. insulare. In D. pygmaum also the club of the antennæ is less compact, and joints $2-6$ are proportionately longer, the apex of the scutellum is more bluntly rounded, and the first joint of the hind tarsus is much shorter in proportion to the second; the series of punctures on the elytra are less deeply canaliculate behind, and their arrangement differs in various details the 2 nd -5 th interstices being proportionately rather wide, \&c.

I have also had for comparison a specimen from the Hawaiian Islands of the species determined by Dr Sharp as D. subquadratum Fairm. * It closely resembles D. pygmaum, having the same short and convex form, and the same kind of punctuation consisting of very fine punctures, each with two radiating short striolæ. It is, however, much larger and the punctuation is very much closer; also its elytra do not narrow slightly from the shoulder to the point where the margin curves round to the apex, as they do in D. pygmoum. It agrees with pygmaum in having the eye not emarginate in front, the antenna somewhat less compact than that of $D$. insulare, and the apex of the scutellum blunt: in the undersides I have been unable to detect any difference; in both the posterior femora are very finely and sparsely, the middle femora much more strongly and closely punctate. The two forms are at any rate very closely allied.

Loc. Seychelles. Mahé : near Morne Blanc, XI. 1908, 2 specimens ; Cascade Estate, $800-1000$ feet, $1908-9,14$ specimens. Mauritius $\dagger$.

Cyclonotum, Erichson.

Cerlostoma, Brullé.

15. Colostoma rufitarse (Boheman).

Cyclonotum rufitarse Boheman, Ins. Caffrar., i. 1848, p. 601.

Coelostoma rufitarse Régimbart, Ann. Soc. ent. France, lxxii. 1903, p. 45.

Cyclonotum rufitarse Régimbart, op. cit., lxxv. 1906, p. 269.

A series of 31 specimens from Aldabra is referred to this species. For comparison I have had a specimen determined as C. rufitarse Boh. from Madagascar (ex coll. Régimbart, Paris Museum), and two determined as C. punctulatum Klug, from Madagascar (ex coll. Sharp, British Museum). The Aldabra specimens agree closely with Régimbart's rufitarse: both they and it are decidedly smaller and considerably less broad in proportion than the specimens of punctulatum, which is in accordance with Régimbart's

* Sharp, Fauna Hawaiiensis, vol. iii. part 5, 1908, p. 578, and Trans. R. Dublin Soc., ser. 2, vol. iii. 1885, p. 218. D. subquadratum was described by Fairmaire as a Cyclonotum (Rev. Mag. Zool. (2), i. 1849, p. 412) and is included by Zaitzev in the genus Calostoma (=Cyclonotum) (Cat. Hydrophil. 1908, p. 404). It was descrilied from Tahiti.

+ Zaitzev in his Catalogue, 1908, p. 402, gives "Madagascar" as the only record of distribution for this species. Régimbart after his description gives only "Île Maurice: Curepipe (Carié)." I am not aware that it has ever been recorded from Madagascar, or anywhere but Mauritius. 
statement of the difference between the two species (Ann. Soc. ent. France, lxxii. 1903, p. 45). Otherwise I have failed to detect any appreciable difference in either upper- or under-sides. In both the punctuation above is rather fine, very close, and nearly even on head, thorax and elytra; the posterior femora are very finely and sparsely punctate, while the intermediate femora have numerous moderately strong punctures; and the palpi are of the same reddish-yellow colour in both. The Aldabra specimens are mostly $5 \mathrm{~mm}$. long, or with head extended $6 \mathrm{~mm}$. : a few are smaller*.

A single specimen from the Seychelles (Mahé ; low country, 1908) is a little shorter and perceptibly broader in proportion than the Aldabra specimens, and a trifle more strongly punctured, especially on the elytra. I am uncertain to which species this should be referred [see footnote; C. punctulatum Klug has been recorded from the Seychelles; see below].

Loc. Aldabra: Takamaka, X.-XI. 1908 (Fryer) ; Picard Island, 1907. Madagascar ; East and South Africa.

16. Colostoma punctulatum (Klug).

Spharidium punctulatum Klug, Ins. Madag., 1833, p. 161 (73).

Colostoma punctulatum Alluaud, Liste Coléopt., p. 232 ; Régimbart, Ann. Soc. ent. France, lxxii. 1903, p. 45 ; Kolbe, Mitt. Zool. Mus. Berlin, v. 1910, p. 24.

Cyclonotum punctulatum Régimbart, Ann. Soc. ent. France, lxxv. 1906, p. 269.

This species is recorded from the Seychelles by Kolbe (l.c.). I only obtained one specimen of the genus Colostoma in the Seychelles, and am uncertain to which species it should be referred : it is mentioned above, under C. rufitarse.

Loc. Seychelles: Mahé (Brauer). Madagascar; East Africa, West Africa (Gabon, \&c., teste Régimbart, l.c.).

Bourdonnaisia, gen. nov. (Plate 14, figs. 12-21).

Corpus ovale, haud fortiter convexum, supra nitidissimum et glabrum. Oculi antice haud emarginati. Antennæ in +9 9-, in $\delta$ 8- vel 9-articulatæ, articulis tribus ultimis

* It is impossible not to feel some doubt as to the identity of these specimens. The types of rufitarse and punctulatum have not been accessible, and it is not absolutely certain that the specimens used for comparison really belong to those species, though they probably do so. Moreover, beyond the difference in size and general form, there do not appear to be real differentiating characters between the two species. I hoped the form of the scutellum might possibly prove a differentiating character, since in a specimen from Brit. East Africa (ex coll. Régimbart, Paris Mus.) the scutellum is much narrower at the base, proportionately longer and consequently more acute at the apex [this specimen is labelled " punctulatum Klug?", but its identity with that species is very doubtful, owing to the relatively narrow form of the insect as a whole and of its scutellum; Régimbart admitted the possibility of the presence of a third species among some rufitarse from East Africa, see Ann. Soc. ent. France, lxxv. 1906, p. 269]: but Régimbart's specimen of rufitarse, the Aldabra specimens, and one at least of the specimens of punctulatum, all agree in having the scutellum broad at the base and relatively short. Neither does the form of the head appear to differentiate the two, though in specimens before me of a third species (C. simplex Sharp, Ceylon) its relative narrowness is at once apparent. The characters separating species of this genus seem in several cases very unsatisfactory, and probably a thorough revision, with examination of genitalia, \&c., is needed. 
clavam laxam formantibus. Palpi maxillares articulo secundo sat elongato ad apicem parum incrassato, articulo tertio quam secundo breviore, articulo ultimo quam tertio parum longiore. Mentum transversum, antice impressum ; palpi labiales breves, articulo secundo elongato, incrassato, dense ciliato, articulo tertio parvo, quam secundo multo breviore. Elytra sine striâ aliquâ. Alæ omnino desunt. Prosternum breve, medio antice haud carinatum. Mesosterni pars elevata haud elongata, antice utrinque marginata, postice cum processu metasterni perfecte conjuncta, suturâ transversâ vix visibili. Metasternum in medio elevatum, antice inter coxas intermedias productum. Segmentum basale abdominis haud carinatum. Tarsi intermedii et postici hirsuti, articulo basali sat incrassato, quam secundo longiore.

Body oval, not very convex, shining and glabrous above: under-surface subopaque, sterna and abdominal segments minutely reticulate, the latter with a very fine short pubescence. Eyes not emarginate in front. Antennce (Pl. 14, fig. 13) 9-jointed in o , 8 - or 9 -jointed in $\delta$ (see below, under B. mahensis), the last three joints forming a loose club; basal joint elongate, about equal in length to those intervening between it and the club taken together, second joint about as broad as basal joint, slightly pyriform, third shorter and much more slender, the following two (or one in B. mahensis f) very short, the sixth (or fifth in B. mahensis of) very short and transverse. Labrum (Pl. 14, fig. 14) hidden under the front of the head, short and transverse, rather deeply sinuate in the middle of the front margin and fringed with hairs on either side. Mandibles (Pl. 14, fig. 15) with an elongate slender apical tooth, the inner margin below this membranous and fringed with hairs. Maxilloe (Pl. 14, fig. 16) with the lobes membranous, the upper one densely setose along its upper margin, the lower one with two setiferous processes at its upper angle and a fringe of setæ on the margin below these; palpi (Pl. 14, figs. 16, 17) with second joint elongate and somewhat swollen apically, third joint shorter than second, fourth joint a little longer than third and blunt at the apex. Mentum (Pl. 14, fig. 18) transverse, impressed and concave in middle in front, with front margin slightly sinuate in middle; lobes of the ligula densely ciliate, projecting beyond the mentum; labial palpi short, second joint elongate, densely ciliate and slightly swollen, third joint very small, only about half as long as second, narrow, blunt at the apex. Elytra without a sutural or any other stria. Wings entirely absent: the most careful examination of a number of specimens of both sexes, in both species, has failed to reveal any trace of these organs. Prosternum very short, not carinate in the middle in front; a narrow lamina extends backwards between the front coxæ, and the ventral part of it projects slightly behind (apparently slightly more in B. mahensis than in B. silhonetta), but scarcely enough to be called a free process. Mesosternum (Pl. 14, figs. 20, 21) forming a rather short elevated ridge, strongly margined on either side in front, and very closely united to the forward-projecting portion of the metasternum, the transverse suture between the two being sometimes scarcely visible: the median portion of the metasternum is elevated and projects some way forward between the middle coxæ to meet the mesosternum. [In $B$. silhouetta the elevation of the mesosternum forms a sharp ridge, which continues as a carina without interruption along the metasternum to its posterior extremity $(\mathrm{Pl}$. 14, fig. 21): in $B$. mahensis the elevated portions of mesosternum and metasternum are broader 
and much blunter, so that there is no sharp central carina (Pl. 14, fig. 20).] Basal abdominal segment without a carina. Tarsi (Pl. 14, fig. 19) nearly as long as the tibiæ, hirsute, with the basal joint somewhat incrassate and considerably longer than the second ; second, third, and fourth joints becoming gradually shorter, fifth joint about as long as third and fourth together.

Type of the genus: Bourdonnaisia mahensis, sp. nov.

It is difficult to speak of the affinities of this genus. In several points it resembles Colostoma, but differs from that genus in its less convex form and general outline, in the absence of a sutural stria and the presence of a seriate arrangement in the punctuation on the elytra, \&c. It appears to be isolated, and is very remarkable in its complete winglessness, and in the sexual dimorphism in the antennæ of one of its species: I am unaware that any other case is known among the Hydrophilidæ of the $\hat{\sigma}$ antenna having a different number of joints from that of the $q$.

Habitat. A long series of the two species was obtained, and the specimens were only found in extremely circumscribed areas on the very summits of the highest peaks of Mahé and Silhouette, at elevations of over 2000 feet, in the highest and dampest forest-zone. These peaks are covered with forest of the endemic "capucin" tree, Northea seychellarum, which has big smooth leathery leaves. These leaves, when fallen and dead, collect in hollows on the ground, lying closely on one another and (owing to the extreme humidity) having films of moisture between them. In this moisture the beetles live: when the leaves are pulled apart and turned over the little creatures are seen crawling on the wet and slimy surfaces, their shape causing them to fit closely down on to the leaf, and their somewhat depressed form being doubtless a convenience in the narrow spaces between the leaves. They were found nowhere but in this particular habitat, and are further remarkable in that one species is confined to Mahé and the other to Silhouette* (an arrangement which, together with the restriction of areas, recalls the distribution of many Hawaiian Coleoptera).

The name Bourdonnaisia is taken from the Governor of Mauritius, Mahé de la Bourdonnais ; the largest island of the Seychelles was named "Mahé" after him in 1744, and the whole group was for some time known as "Les Îles de la Bourdonnais $\uparrow . "$

17. Bourdonnaisia mahensis, sp. nov. (Plate 14, fig. 12).

§ิq. Sat breviter ovalis, corpore supra nigro-piceo, subtus piceo-ferrugineo, palpis antennisque flavis, harum clavis nigrescentibus, tarsis flavo-ferrugineis; capite lævi, ad marginem anteriorem rarius tenuissime punctulato; prothorace scutelloque lævibus; elytris marginibus externis postice parum explanatis, sat fortiter, crebre, et regulariter seriatim punctatis, punctis serierum alternatarum parum fortioribus. Long. corp. ca. $1 \frac{3}{4} \mathrm{~mm}$.

f, antennis 8 -articulatis; , antennis 9-articulatis.

* The finding of these beetles is referred to in the writer's introductory paper, Trans. Linn. Soc. London, ser. 2, Zool., vol, xiv. 1910, pp. 25, 29, 33.

$\dagger$ See J. Stanley Gardiner, in the Geographical Journal for February, 1907, p. 152. 
Rather shortly and broadly oval, shining pitchy-black above, the base of the thorax sometimes narrowly testaceous and the suture of the elytra sometimes vaguely ferruginous; under-side dark pitchy ferruginous ; palps and antennæ yellow, clubs of the latter blackish. Submentum bearing a transverse series of long hairs (absent in B. silhouettce), standing in a slightly curved line. Head with very fine scanty punctuation near the anterior margin ; rest of head and prothorax quite smooth and impunctate (only under a compound microscope is an extremely scanty and obsolete punctuation visible). Scutellum smooth. Elytra with the outer margins slightly flattened towards the apex, rather strongly and regularly punctured, the punctures arranged in a number of closely-approximated series; in each series the punctures are well spaced out, at some distance from one another, and those in each alternate series are slightly stronger. The seriate nature of the punctuation is not always quite evident at first sight, but is very clearly visible if an elytron is removed and examined separately. Certain peculiarities of the sterna are mentioned in the description of the genus (see Pl. 14, fig. 20).

Antenno (Pl. 14, fig. 13): in the of the antenna consists of only eight joints, as opposed to nine in the $q$; it has only two short transverse joints between the slender elongated third joint and the club, instead of three as in the $q$. When balsampreparations of the $\delta$ antenna are viewed as transparencies under a high power ( $\frac{1}{6}$-inch objective), there is an indication that the proximal of these three transverse joints, i.e. that which corresponds to the 4 th joint in the $o$, may have fused with the third joint, thereby reducing the number in the of from 9 to 8 . Usually the number of joints cannot be surely determined without making balsam-preparations, and there is no other external sexual differentiation: but when several transparent balsam-mounts were made, the sexes were easily distinguished by the genital structures within the apex of the abdomen, and it was then seen in each case that the $\delta$ antenna has 8 joints, the +99 .

The series consists of about 100 specimens.

Loc. Seychelles. Mahé : summit of Morne Pilot, over 2000 feet, X.-XI. 1908 ; high forest between Trois Frères and Morne Seychellois, about 2000 feet, 9 and 10 . XII. 1908 ; slopes of Morne Seychellois, about 2000 feet, 4. II. 1909 ; high forest above Cascade Estate, I. 1909 ; summit of “Montagne Anse Major" (Mare aux Cochons district), about 2000 feet, 1. II. 1909.

18. Bourdonnaisia silhouetta, sp. nov. (Plate 14, figs. 16 and 21).

๙̊․ Major, magis elongata, elytris parum subtilius punctatis; mesosterno et metasterno in medio argute longitudinaliter carinatis. Long. corp. ca. $2 \frac{1}{4} \mathrm{~mm}$.

$\hat{\delta}$ et $q$, antennis 9 -articulatis.

Much larger ; form more elongate-oval as contrasted with the short broadly-oval form of $B$. mahensis. Elytra with the margins a trifle less explanate behind, and with the punctuation slightly finer. Maxillary palpi darker in colour. Thorax sometimes testaceous on either side at the base. Peculiarities in the form of the sterna (see Pl. 14, fig. 21), as compared with that of $B$. mahensis, are mentioned in the description of the genus. 
Antenno: these organs are 9 -jointed in $\hat{\delta}$ and $q$, and $I$ have been unable to detect any difference in form between those of $\hat{s}$ and those of $q$. Several balsam-preparations were made, and the sexes distinguished by the genital structures, as in the case of the preceding species.

The series consists of 32 specimens.

Loc. Seychelles. Silhouette : highest peak, about 2400 feet, IX. 1908.

Cercyon, Leach.

All the four species of this genus found in the Seychelles belong to the subgenus Cercyon s. str. The ventral surface of the mesosternal lamella is very narrow (in $C$. fructicola and C. laticollis linear, in C. uniformis very slightly broadened in the middle and tapering to a point before and behind) and the front of the metasternum is not cut out to receive the posterior end of this lamella. The front tibiæ are simple (not emarginate outwardly before the apex): the sides of the prothorax are not scalloped before the base : the convexity of thorax and elytra forms a single curve (except when the specimens are unnaturally extended).

19. Cercyon fructicola, sp. nov.

Ovalis, depressus, angustus, lateribus subparallelis, nitidus, parcissime tenuissimeque pubescens; supra omnino piceo-niger, palpis antennisque rufo-testaceis, harum clavis infuscatis, corpore subtus pedibusque omnino rufo-ferrugineis: capite pronotoque modice fortiter et crebre punctatis : elytris sat profunde punctato-striatis, intervallis ad basin fere planis, ad apicem parum convexis, sat tenuiter crebre punctatis. Long. corp. (incl. cap.) $1 \frac{3}{4}-2 \frac{1}{2} \mathrm{~mm}$.

Form oval, depressed, rather narrow, with sides subparallel : in some specimens the thorax appears very slightly broader at the base than the elytra: from the base to about half the length the sides of the elytra are nearly parallel or very slightly curved, beyond that point they curve inwards to the not very blunt apex. Body above entirely pitchyblack, shining, only the pronotum and scutellum sometimes a trifle more dilute, and the front margin of the head and front and hind margins of the pronotum narrowly reddish; antennæ and palps reddish-testaceous, clubs of the antennæ infuscate; body beneath and legs entirely ferruginous. Very fine short hairs rise sparsely from some of the punctures on the head, pronotum, and from the intervallar punctures of the elytra. Head with front margin subtruncate, very slightly rounded; moderately, strongly and fairly closely punctured, intraocular systematic punctures not very distinct. Pronotum with punctuation about equal to that of the head, with sides gradually narrowing from the base forwards and slightly curved. Scutellum considerably longer than broad at base, smooth, with only a few punctures. Elytra each with nine rather deep punctate striæ, the punctures close together near the base, separated by twice their own diameter or more in the posterior part, strongest in the outermost striæ: striæ $1-5$ reach to the base, 1 (the sutural) bending outwards on either side of the scutellum; 6 is abbreviated before the 
base by the humeral callus; 7 reaches to the base ( 5 and 7 curving very slightly towards one another, on either side of the callus, at the base); 8 and 9 are abbreviated a little before the base; at the apical end, $1-3$ run to the apex, 4 unites with 9,5 with 8 , enclosing 6 and 7 : intervals nearly flat, the outermost ones (and the inner ones towards the apex) slightly convex, with rather numerous fine punctures, and with a not quite smooth appearance in the general surface. Mesosternum with the raised lamella very narrow, linear.

This species appears to resemble Cercyon nigerrimus Régimbart (Ann. Soc. ent. France, lxxii. 1903, p. 49 ; known from Mauritius), judging from the description of that species. But M. Lesne, to whom I submitted a specimen of Cercyon fructicola for comparison, informs me that the unique type of Cercyon nigerrimus is larger, decidedly shorter and more convex, with the pronotum much less clearly punctuated, \&c.

74 specimens.

Loc. Seychelles. Silhouette: near Mont Pot-à-eau, ca. 1500 feet, VIII. 1908; Mare aux Cochons plateau and forest above, ca. 1000 feet and over, VIII.-IX. 1908. Mahé: high forest of Morne Blanc, X. 1908; high damp forest between Trois Frères and Morne Seychellois, 1500-2000 feet, XII. 1908 ; Cascade Estate, ca. 1000 feet, and forest above, 1908-9; Mare aux Cochons district, 1500-2000 feet, I.-II. 1909. Praslin: Côtes d'Or Estate, XI. 1908.

The above list shows that in Mahé and Silhouette this species was taken principally if not entirely in the mountain-forests. It was often found in rotting fruit, especially oranges and "jak," often in company with Cercyon uniformis, Dactylosternum insulare, \&c. (see under those two species).

20. Cercyon laticollis, Régimbart.

Cercyon laticollis Régimbart, Ann. Soc. ent. France, lxxii. 1903, p. 48.

13 specimens : the determination was first made by Monsieur d'Orchymont, and confirmed by Monsieur Lesne, to whom a specimen was submitted. The specimens agree well with Régimbart's description. The lateral margins of the prothorax, when viewed from the side, are seen to be slightly sinuate behind the anterior angles. On the elytra the 1st (sutural) and 2nd striæ do not reach quite to the base, 3, 4 and 5 almost reach the base, 6 is abbreviated a little before the base, the callus being situated between its front end and the base, 7 reaches further forward than 6,8 and 9 end some distance from the base, but 9 reaches further forward than 8 : at the apical end, in at any rate most of the specimens, stria 4 unites with 9 , and 5 with 8 , enclosing 6 and 7 : the large punctures of the striæ lie in each case on the outer side of the stria : the intervals between the inner striæ are nearly flat, the outer ones convex, the intervallar punctures being extremely fine and not close and bearing exceedingly fine hairs: the suture is darkened near the apex.

I have distinguished a $\hat{\delta}$ and a $q$ by dissecting out the genitalia, but can see no external difference between them.

Loc. Seychelles. Silhouette: Mare aux Cochons, VIII. 1908. Mahé : Long Island, VII. 1908 ; low country on the main island. Praslin: Côtes d'Or Estate, XI. 1908. Madagascar. 


\section{Cercyon laticollis Régimbart, var.?}

A single specimen, apparently immature, differs from the preceding series. The sides of the elytra are more rounded and their greatest width is behind the base, instead of their being widest at the base and tapering gradually; the inner striæ are strongly impressed right up to the base, instead of becoming faint in the region of the scutellum, and the intervals appear slightly less smooth. The sides of the pronotum are not sinuate behind the anterior angles. The scutellum is narrower at the base and proportionately more elongated. At first it seemed probable that this might be the $q$ of $C$. laticollis : but as stated above dissection has revealed the presence in the series of that species of $\delta$ and $q$ not differing externally, and the true position of this specimen must therefore remain doubtful.

Loc. Seychelles. Silhouette: Mare aux Cochons, IX. 1908.

21. Cercyon uniformis, Sharp.

Cercyon uniformis Sharp, Trans. Ent. Soc. London, 1890, p. 357.

Determined by comparison with the type. A series of over 160 specimens, showing considerable variation in size, but apparently constant in coloration, \&c.

Loc. Seychelles. Mahé: high forest of Mornes Blanc and Pilot, ca. 2000 feet, including some from strong-smelling rotting fruits of Pandanus seychellarum on summit of Morne Blanc, X. 1908 ; country above Port Glaud, 500-1000 feet; Cascade Estate, ca. 1000 feet, and forest above, large numbers, 1908-9; Mare aux Cochons district, 1000 -2000 feet, including some from forest on summit of "Montagne Anse Major," 1909. Silhouette: near Mont Pot-à-eau, ca. 1500 feet, VIII. 1908; Mare aux Cochons, over 1000 feet, 1908.

I found this species very common in rotting fruit, especially oranges and "jak" (Artocarpus integrifolia), where it is frequently obtained in company with Dactylosternum insulare, Cercyon fructicola, \&c. It can be seen from the above locality-list that it is also found in the dampest endemic forests and at the highest elevations, which is remarkable, as it is probably an introduced species. It is recorded also from Ceylon and India.

\section{Cercyon sp.}

Length (not incl. extended head), $1 \frac{1}{2} \mathrm{~mm}$. Oval, with the greatest width a little before the middle of the elytra, narrowed before and behind with the apex of the elytra bluntly rounded, convex; head and pronotum shining, elytra subopaque. Head black, with the extreme anterior margin of the epistome very narrowly testaceous; palps and antennæ pale testaceous, the latter with blackish clubs: pronotum pitchyblackish, with anterior margin narrowly and lateral margins more broadly testaceous, and posterior margin obscurely reddish. Elytra with the basal quarter obscurely reddish, the extreme base and scutellum being darker (blackish, especially in the middle) : from about $\frac{1}{4}$ to about $\frac{3}{4}$ the length is occupied by a broad black band extending from about the region of the 8 th stria to the suture, and stretching obliquely inwards and backwards; in front this black band is vaguely bounded, shading gradually into the basal reddish portion, but behind it is more sharply bounded; behind it the whole apical portion of the elytron is pale yellowish testaceous, excepting the interval between 
suture and 1st stria, which is darker; laterally the testaceous colour extends along the side of the elytron between the black band and the side margin, joining in front with the outer extremity of the basal reddish area, but not quite reaching the humeral angle, which is darker. Legs and feet reddish-testaceous.

Head and pronotum finely and rather closely punctate, the pronotum with anterior and posterior angles obtuse, the latter very widely so: the fine posterior margin of the pronotum is seen under a high power to be interrupted by punctures. Scutellum minute, rather narrow, acute at apex, with a few punctures. Elytra with 10 punctate striæ, the punctures larger and nearer together near the base, separated by several times their own diameter behind; stria 1 (the sutural) and striæ $2-5$ reach nearly to the base; stria 6 ends in front further from the base; striæ $7-9$ end in front about $\frac{1}{4}$ the length of the elytron from the base (the 7 th being just traceable further forward by a few punctures); stria 10 reaches about as far forward as 6 : there is a slight callosity at the base just outside the anterior extremity of the 5th, and in front of that of the 6th, stria. Behind, the 10th (outermost) stria ends at about the middle of the elytron; 9 and 8 can be traced, running parallel to the outer margin, right round the apex to the suture, and they thereby prevent striæ $1-5$ from reaching the apex, while 6 and 7 are abbreviated some way further forward. The intervals are scarcely convex near the base, but moderately convex behind; they bear very fine widely-separated punctures, much smaller and finer than those on the striæ. Under a very high power the subopacity of the general surface of the elytra is seen to be due to the presence of an excessively fine, minute, and close dotting.

This may well be a new species. I have found nothing agreeing with it in any of the collections in the British Museum. Monsieur d'Orchymont suggested that it might possibly be allied closely to crenulatus Régimbart (India, Java, \&c.) or crenatostriatus Régimbart (Mauritius); but Monsieur Lesne, to whom I submitted it, informs me that both those species are much larger and differently sculptured. As I have only a single specimen, and have been unable to see a number of species, I have thought it best to describe but not to name it.

Loc. Seychelles. Mahé: Anonyme Island, 9. I. 1909, 1 specimen.

Paroosternum, gen. nov. (Plate 14, fig. 22).

Oosterno peraffine, sed differt in formâ sternorum. Pars media prosterni haud carinata, sed tabulam oblongam marginatam, superficie fere planâ (perparum concavâ) formans. Mesosternum (ut in Oosterno) aream ovatam elevatam formans. Metasternum in medio valde elevatum, sed impressione longitudinali distinctâ in medio partis elevatæ: lineis femoralibus ad angulos anteriores continuatis.

Body somewhat elongate-oval, moderately convex, with lateral margins of thorax and elytra not in the least explanate; above shining, with very scanty fine hairs on the elytra; beneath, central part of metasternum shining, its sides and the abdominal segments subopaque and bearing fine short pubescence. Head deflexed in front, labrum hidden. Antennce 9-jointed: basal joint elongate, longer than joints $2-6$ 
taken together, joint 2 short but longer than broad, joint 3 narrower, short but also longer than its breadth, 4 and 5 very short, 6 very short and transverse, applied to the base of the club, joints $7-9$ forming a very compact obovate club*. Maxillary palpi with second joint considerably swollen distally, third joint very slightly swollen distally, fourth joint slightly swollen in the middle, and subequal to, or slightly longer than the third (owing to insufficiency of material it is impossible to make a preparation of the mouth-parts, hence the relative lengths of joints cannot be exactly determined). Mentum narrowed in front, scarcely impressed in the middle of the front margin. Wings examined in one specimen and found fully developed, about twice as long as elytron. Prosternum not carinate in the middle, but with its median portion forming an elevated oblong area, finely-margined on either side, with surface slightly concave in front, and with hind margin angularly excised (between the anterior coxæ) to receive the apex of the elevated part of the mesosternum (see Pl. 14, fig. 22). Mesosternum forming an elevated, narrowly ovate, margined area, acuminate in front, with surface concave. Metasternum strongly elevated in the middle, with a marked longitudinal impression in the middle of the elevated portion; in front it is only slightly produced between the middle coxæ, and is depressed, so that the middle of the front margin is hidden under the posterior extremity of the elevated mesosternal area: the "femoral lines" $\dagger$ are very clearly marked and uninterrupted, reaching to the anterior corner of the metasternum : in their front part they are fine raised lines, while their posterior portion is formed by the edge of the elevated median part of the metasternum. Basal abdominal segment with a median longitudinal carina. Anterior tibio with the outer margin bearing about 5 short spines distally, and rounded off at the apex. Tarsi 5-jointed, scarcely hirsute, with the basal joint distinctly longer than the second.

Type of the genus: Paroosternum degayanum, sp. nov.

This minute insect is very closely allied generically to Oosternum Sharp (Biol. Centr.-Am., Col. i. 2, p. 112, Pl. 3, fig. 16), but differs from it in the form of the sterna. Two species of Oosternum are known, O. costatum Sharp (l.c.) from Central America, and $O$. sorex (Sharp) from Japan (described as Cercyon sorex, Trans. Ent. Soc. London, 1874, p. 418): I have examined specimens of both these and compared them closely side by side with Paroosternum. In both genera the middle part of the prosternum is distinctly differentiated from the lateral parts, but in Oosternum this middle part has an elevated central longitudinal keel and sloping sides, while in Paroosternum it forms an oblong elevated area without a trace of a median keel: this is the principal difference and is alone sufficient to separate the genera. The oblong elevated table of Paroosternum recalls the prosternum of some Histeridæ: in the one known species its surface is very slightly concave. The genera are closely similar in the form of the mesosternum (the surface of the ovoid area being however

* As in the Cercyon spp. which I have examined, a kind of transverse ridge neair the apex of the terminal joint of the club makes it appear as if there were a small fourth joint at the apex.

+ "Schenkellinien": see Ganglbauer, Die Käfer von Mitteleuropa, iv, 1, p. 273 (1904).

SECOND SERIES-ZOOLOGY, VOL. XVI. 
slightly concave in Paroosternum degayanum but not at all concave in Oosternum costatum), and in having the front of the metasternum depressed and sunk beneath the posterior margin of the elevated mesosternal area, instead of united with it as in, e.g., Cryptopleurum. Paroosternum degayanum has a marked median longitudinal impression on the metasternum: in the specimens of Oosternum costatum examined there is no trace of impression on the metasternum, which is slightly convex; in the one specimen of Oosternum sorex which I have seen the elevated median part of the metasternum is slightly concave in the middle, but this concavity is quite different from the marked longitudinal impression of Paroosternum degayanum. The latter has its femoral lines continued to the anterior corners of the metasternum, while in Oosternum costatum they become obsolete in front.

23. Paroosternum degayanum, sp. nov. (Plate 14, fig. 22).

Elongato-ovalis, sat convexus, nitidus, fuscus, palpis antennisque testaceis, harum clavis infuscatis, pedibus fusco-testaceis; capite prothoraceque distincte sat rare punctatis, hoc serie basali punctorum fortiorum; elytris striis impressis et sat fortiter punctatis, interstitiis haud elevatis et tenuiter sat rare punctatis. Long. corp. circa $1 \mathrm{~mm}$.

The surface is shining, but a very fine reticulation is visible under a compound microscope. The pubescence of the upper surface is not easy to see, consisting of extremely scanty and fine pale hairs arising from the punctures on the interstices of the elytra (in these specimens there are no hairs on head or thorax, but possibly they are broken off). The punctures on head and thorax are very distinct but not close: the thorax has a regular series along its base, a feature which is also present in Oosternum costatum Sharp. The elytral striæ are strongly impressed and strongly punctate; the interstices finely and not closely punctured, not in the least raised into costæ or carinæ, their median parts being almost flat.

Oosternum costatum Sharp is much less shining and more strongly reticulated: its pubescence is much more conspicuous: its head and thorax are more strongly and closely punctured: and the alternate interstices of the elytra are raised into costæ. Oosternum sorex (Sharp) is much larger than Paroosternum degayanum and quite different from it in general appearance.

This species is dedicated to Mr J. A. de Gaye, F.L.S., who during the time that he lived in the Seychelles was a keen student of the entomology of the islands.

Loc. Seychelles. Mahé : from near Morne Blanc, X.-XI. 1908, 2 specimens.

\section{Histeridæ.}

16 species are here enumerated as occurring in the islands visited by the Expedition. The number previously recorded was 8 , and of the 8 species now added 5 are new to science. The 16 species represent 6 genera (in three of which two subgenera are represented). 13 out of the 16 species are actually represented in the collection made by the Expedition, while the remaining 3 (Platysoma richteri, Carcinops 14-striata, Saprinus erichsoni) were found only by previous collectors. 
The following table shows the distribution of the species so far as known:

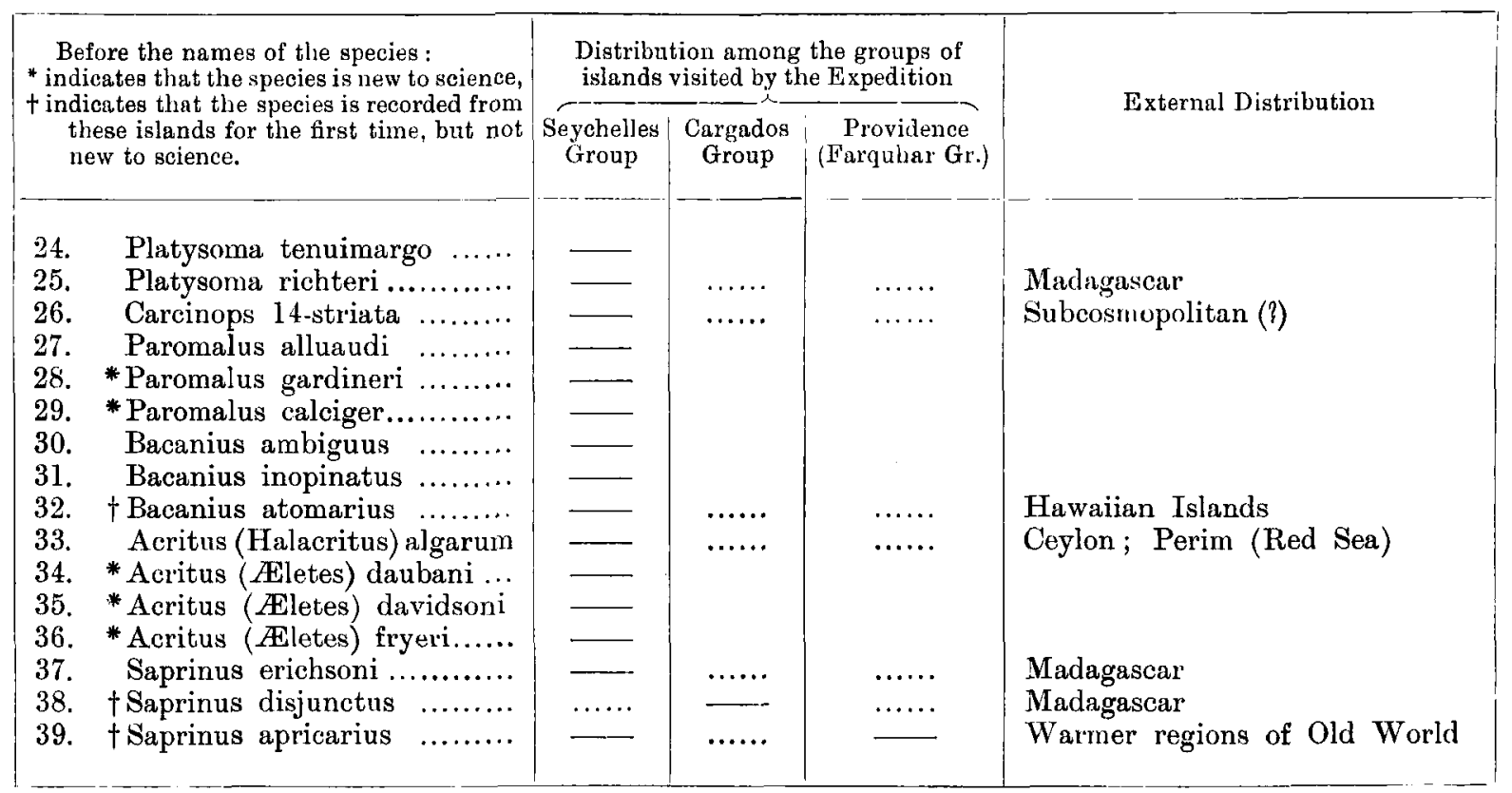

It will be seen that no Histerid was collected by the Expedition in the Chagos or Amirantes groups, nor was any found by Mr Fryer during his 4 months' stay in Aldabra or his visits to the neighbouring islands : nor have any species ever been recorded from these groups.

The table shows that 15 species have been found in the Seychelles, 14 of them only in that archipelago, and 1 widely-distributed species both in that archipelago and also in the coral-island of Providence: while the remaining 1 species (Saprinus disjunctus) was found only in the coral-islands of the Cargados Carajos group.

Of the 15 species found in the Seychelles, 9 are known only from those islands, and most of these are probably endemic. Of these 9 species, Platysoma tenuimargo has been stated to be closely allied to a New Guinea species (see p. 224): Paromalus alluaudi is said to be closely allied to an Eastern species (see p. 225): Paromalus gardineri (very possibly not endemic) in some ways resembles a Ceylon species. Nothing can be said about the affinities of Paromalus calciger, the two species of Bacanius, and the three species belonging to the subgenus Aletes of Acritus. As stated on p. 230, it appears that no member of the whole great genus Acritus is known from Africa, and only two species from Madagascar; and until such minute creatures as Bacanius and Acritus are more collected and known, it is almost idle to speculate about the Seychelles species.

Of the 6 species found in the Seychelles but known also from elsewhere, two (Platysoma richteri, Saprinus erichsoni) are Madagascar species: one (Bacanius atomarius) is known from the Hawaiian Islands: one (Acritus algarum, a coast species) from Ceylon and Perim Island: while two are very wide-spread (Carcinops 14-striata and Saprinus apricarius, the latter of which was also found in Providence).

The one species, Saprinus disjunctus, found in the Cargados group is a Madagascar species. 
Local distribution within the Seychelles group. As far as my own experience goes, 8 out of the 9 species known only from these islands were found in the endemic mountain-forests, but several of these were found also in lower, cultivated places: it is noteworthy that one of them (Bacanius ambiguus), which I found under the bark of decaying wood in several islands, both in the forests and in cultivated places, was originally found by Alluaud under seaweed on a sandy beach, in company with the seaweed-species Acritus algarum. The remaining peculiar species (Paromalus gardineri) was only found on a cultivated islet (Long Island). On the other hand, of the non-peculiar species, Acritus algarum is a coast species inhabiting seaweed, and the wide-spread Saprinus apricarius was obtained in an outlying coral-island (Bird Island) which possesses none of the endemic vegetation or other special characteristics of the Seychelles. The species known from the Hawaiian Islands was found on Cascade Estate, but only two specimens were collected, and I have no record of the exact spot, whether forest or otherwise. The other 3 non-peculiar species were not collected by this Expedition. The material is in some cases too small to judge of the local distribution: but I think there is some indication of a division between endemic forms inhabiting the endemic mountain-forests, and non-endemic forms inhabiting cultivated places and the coasts (cf. vol. xv. of these Transactions, 1912, bottom of p. 218 and p. 219).

Reduction of wings. A remarkable case of reduction of these organs to minute vestiges has been discovered in Acritus (Halacritus) algarum: details are given on p. 230. As mentioned there, reduced wings had been found in two Hawailan species of Acritus, but species belonging to a different subgenus, Eletes: lack of material prevented my examining the wings in the Aletes from the Seychelles. In Bacanius ambiguus and inopinatus I found the wings fully developed. They were not examined in any of the other genera or species.

\section{Platysoma, Leach.}

\section{Subgenus Platysoma, s. str.}

24. Platysoma tenuimargo, Schmidt.

Platysoma tenuimargo Schmidt, Bull. Soc. ent. France, 1893, p. 100 ; Alluaud, Liste Coléopt., p. 108 ; Kolbe, Mitt. Zool. Mus. Berlin, v. 1910, p. 21.

I am indebted to $\mathrm{Mr}$ George Lewis for the determination of this species. It is stated by Schmidt to be closely allied to $P$. conditum Marseul, from New Guinea. The collection contains 12 specimens.

Loc. Seychelles. Silhouette : forest near Mont Pot-à-eau, ca. 1500 feet, VIII. 1908 ; forest above Mare aux Cochons, over 1000 feet, IX. 1908 (one specimen recorded as found in the decayed head of a felled Verschaffeltia palm); low coconut-planted country near coast at Pointe Étienne, IX. 1908. Mahé: Cascade Estate, over 800 feet. La Digue : 1892 (Alluaud). 
Subgenus Cylistosoma, Lewis, Ann. Mag. Nat. Hist., ser. 7, xv. 1905, p. 302.

25. Platysoma (Cylistosoma) richteri, Schmidt.

Platysoma richteri Schmidt, Ent. Nachr., xv. 1889, p. 335 ; id., Bull. Soc. ent. France, 1893, p. 99 ; Alluaud, Liste Coléopt., p. 108 ; Kolbe, Mitt. Zool. Mus. Berlin, v. 1910 , p. 21 .

Not obtained by the Percy Sladen Trust Expedition.

Loc. Seychelles: La Digue, 1892 (Alluaud). Madagascar.

\section{Carcinops, Marseul.}

26. Carcinops quattuordecimstriata (Stephens).

Carcinops quattuordecimstriata (Stephens); Lewis, Syst. Cat. Histeridæ, p. 38, 1905 ; Bickhardt, Coleopt. Cat., Histeridæ, p. 60, 1910.

Carcinops pumilio (Erichson); Kolbe, Mitt. Zool. Mus. Berlin, v. 1910, p. 21.

Not obtained by the Percy Sladen Trust Expedition. The Catalogues of Lewis and Bickhardt, referred to above, are followed in placing pumilio Er. as a synonym of quattuordecimstriata Steph. Lewis gives as the distribution "Cosmopolitan"; while Bickhardt gives South and West Europe, and North America.

Loc. Seychelles. Mahé: cultivated country (Brauer).

\section{Paromalus, Erichson.}

Subgenus Paromalus, Lewis, Ann. Mag. Nat. Hist., ser. 7, xix. 1907, p. 316.

All three of the species found in the Seychelles belong to this subgenus: that is to say, they have no sutural stria on the elytra, and the keel of the prosternum has definite striæ on either side and is not narrowed in front of the coxæ (see Lewis, op. cit., p. 318, fig. 4).

27. Paromalus alluaudi, Schmidt.

Paromalus alluaudi Schmidt, Bull. Soc. ent. France, 1893, p. 100; Alluaud, Liste Coléopt., p. 109 ; Kolbe, Mitt. Zool. Mus. Berlin, v. 1910, p. 21.

$1 \hat{c}$ and $1 \hat{q}$, determined by comparison with Schmidt's actual type $\hat{\delta}$ and $q$ and with another typical pair, all sent by Monsieur Alluaud. I have closely compared upper and under surfaces of both sexes side by side; the $q$ obtained by me has the prosternal striæ a little wider apart, but in all other respects, including the remarkable sculpture, it agrees with the specimens received from Alluaud: the of agrees closely.

Schmidt states that this species has the facies of certain Indian species, and is very closely allied to Paromalus mendicus Lewis from Japan and Java.

Loc. Seychelles. Silhouette : forest above Mare aux Cochons, well over 1000 feet, IX. 1908, 1 io and 1 q. La Digue, in numbers under bark, 1892 (Alluaud). 
28. Paromalus gardineri, sp. nov. (Plate 14, fig. 23).

ร์. Sat latus, ovalis, niger, nitidus, antennis pedibusque rufo-piceis; capite dense subtiliter punctato, striâ marginali integrâ; prothorace dense subtiliter punctato, striâ marginali anteriore integrâ; elytris fortiter dense punctatis, basi extus parum impresso fortiusque punctato, striâ dorsali externâ unâ sat obsoletâ, ad medium abbreviatâ, subhumerali tenui, vix visibili, suturali nullâ; propygidio dense sat fortiter punctato; pygidio subtilissime punctulato, ad basin fortius punctato; prosterno inter strias angusto, basi parum latiore, striis subparallelis, inter coxas leviter sinuatis; mesosterno striâ marginali antice late interruptâ, striâ transversâ arcuatâ impressâ, ad latera abbreviatâ ; meso- et metasterno et segmento primo abdominis sparse subtilissime sat obsolete punctulatis. Long. corp. ca. $2 \mathrm{~mm}$.

Form oval, not oblong, rather broad, slightly convex; head and prothorax densely and very finely punctured, the former with marginal stria complete, the latter with the stria along the front margin fine but complete. Elytra densely and strongly punctured, punctures finer towards the inner basal angle; the base outside the rniddle with a very slight transverse impression (more marked in some specirnens than in others) and with conspicuously strong punctures, which continue also to some extent along the basal part of the dorsal stria; with one dorsal stria, outside the middle, rather broad at the base, somewhat obsolete and difficult to see from certain aspects, terminating at about the middle of the length of the elytron; there is an extremely fine subhumeral stria, only visible with difficulty; the suture is slightly elevated behind. Propygidium and pygidium devoid of peculiar sculpture in either sex, and the same in both sexes, the former fairly densely and strongly punctate, the latter with fairly strong punctures just along the base and with the rest of the surface to the apex extremely finely punctulate. Prosternum with the anterior lobe very finely punctulate, the portion between the striæ narrow, very slightly broader at the base, the striæ subparallel, very slightly sinuate between the coxæ. Mesosternum with the marginal stria widely interrupted in front, just turning the angle but not reaching nearly to the emargination in the middle of the front margin; transverse stria impressed, in the form of an arch with the convex side directed forwards, not reaching to the sides. Meso- and metasternum and 1st abdominal segment very finely, not closely, and rather obsoletely punctulate, the punctuation becoming a little stronger at the posterior and outer parts of the 1st abdominal segment. Anterior tibia with four teeth externally (Pl. 14, fig. 23). I have found no means of distinguishing the sexes without dissection of the genitalia.

Specimens were submitted to Mr George Lewis, who failed to identify this species with any in his collection, and considers that it is almost certainly new. He sent me for comparison a specimen of Paromalus biarculus Marseul from Ceylon. This closely resembles Paromalus gardineri in some respects, especially in the form of the mesosternal transverse stria and of the under surface as a whole; but is abundantly distinguished by its greater breadth, more oblong form, much finer punctuation of the upper surface, by having the anterior marginal stria of the prothorax widely interrupted 
in the middle, and by the special sculpture distinguishing the pygidium of the for from that of the $q$. Though Paromalus gardineri appears to be new, it is doubtful whether it is truly endemic to the Seychelles, since (unlike the other two Seychelles species) it was not found in the forests, but on a cultivated islet. It is dedicated to Professor J. Stanley Gardiner.

Loc. Seychelles. Mahé: Long Island, VII. 1908, 10 specimens, 5 of which were recorded to have been found in a decaying stem of a coconut-palm.

29. Paromalus calciger, sp. nov. (Plate 14, figs. 24, 25).

§. Angustus, oblongus, subconvexus, rufo-piceus, nitidus; capite sat dense punctato, striâ marginali haud ante oculos continuatâ; prothorace dense punctato, utrinque pone oculos parum impresso, antice angustato lateribus sat rotundatis, striâ marginali pone caput integrâ; elytris dense fortiter punctatis, striis nullis ; propygidio pygidioque sat dense subtiliter punctatis; prosterno inter strias angusto, basi parum latiore, striis subparallelis, inter coxas parum sinuatis ; mesosterno ante striam transversam punctato, striâ marginali antice late interruptâ, striâ transversâ integrâ, biangulatâ, parte mediâ latâ parumque arcuatâ, partibus lateralibus oblique retrorsum currentibus; metasterno segmentoque primo abdominis dense sat fortiter punctatis, punctis ad latera fortioribus ; tibiis anticis apice subito conspicueque incurvatis, extus 4-dentatis. Long. corp. (incl. cap.) $2 \mathrm{~mm}$.

Form narrow, neither strongly depressed nor strongly convex. Head rather densely and strongly punctured, a very high power showing finer punctures among the larger ones: the stria is present on either side only as far as a point just above the front margin of the eye: the clypeus (in one specimen at least) is obsoletely impressed on either side. Prothorax with disc somewhat convex, narrowed in front with sides slightly rounded, densely punctured, with a slight impression in front on either side behind the eye, with the marginal stria fine but continuous along the front margin. Elytra densely and strongly punctate, the punctures near the suture becoming fine towards the base; there is a slight obsolete impression (in some aspects hardly visible) at the base just outside the middle. Propygidium and pygidium finely and fairly densely punctured. Prosternum with the space between the striæ narrow, slightly broader at the base; striæ subparallel, slightly sinuate between the coxæ, converging slightly (but not meeting) at the extreme apex: anterior lobe finely punctate. Mesosternum (Pl. 14, fig. 25) with marginal stria present at the sides, widely interrupted along the front margin; it just turns the corner of the front margin, but does not reach the median emargination : transverse stria complete and distinct, biangulate, the middle part wide (about as wide as the two lateral parts together) and slightly arcuate (with convex side of the curve directed backwards), the lateral parts running obliquely outwards and backwards and also slightly curved: meso-metasternal suture just visible from certain aspects with a very high power: in front of the transverse stria the mesosternum is punctate, but behind, between it and the suture, almost impunctate. Metasternum and 1st abdominal segment densely and rather strongly punctured, punctures stronger at the sides.

The anterior tibice are bent strongly inwards at the apex, forming a conspicuous 
blunt heel-like projection behind the base of the tarsus (whence the name calciger, "heelbearer"): anterior and posterior aspects are figured, Pl. 14, fig. 24, $a$ and $b$ (the anterior tibia of Paromalus gardineri is also figured, Pl. 14, fig. 23, for comparison, to show the more normal form). Externally the tibiæ are 4-toothed.

In a single specimen the remarkable form of the tibiæ might well be considered to be an abnormality or monstrosity: but since there are three specimens all having them formed in exactly the same way, it must be taken to be normal. All three specimens, however, have been shown by dissection to be $\hat{\delta}$, so the form of the tibiæ may be a sexual character. In addition to this, the species is characterised by its narrow subconvex form and dense punctuation, by having the frontal stria widely interrupted and the anterior thoracic stria complete, and by the form of the mesosternal transverse stria. It is absolutely distinct from either of the other Seychelles species. As to its affinities I can say nothing, not having sufficient knowledge of the genus : but I have seen no species with such tibiæ, nor closely resembling it in other ways, in the British Museum, nor have I read any description closely agreeing with it.

Loc. Seychelles. Silhouette: endemic forest near Mont Pot-à-eau, ca. 1500 feet, VIII. 1908, 1 f̊ (Type). Mahé : high forest of Morne Blanc, X. 1908, 1 ^) Cascade Estate, 800 feet or more, 1 ๙ .

\section{Bacanius, Leconte.}

\section{Bacanius ambiguus, Schmidt.}

Bacanius ambiguus Schmidt, Ann. Soc. ent. France, 1893, Bulletin, p. 101 ; Alluaud, Liste Coléopt., p. 110 ; Kolbe, Mitt. Zool. Mus. Berlin, v. 1910, p. 21.

A large series, determined by comparison with cotypes kindly lent by Monsieur Alluaud. There is considerable variation in size, length (not including the head) varying from less than 0.8 to $0.9 \mathrm{~mm}$.

Wings. I have examined these organs in 5 specimens (4 from Silhouette and 1 from Félicité), and find them fully developed, about twice the length of the elytra.

Loc. ${ }^{*}$ Seychelles. Silhouette: from under bark of felled dicotyledonous trees among coconut-plantations near coast, Pointe Étienne, 17. IX. 1908, over 100 specimens; from forest near Mont Pot-à-eau, ca. 1500 feet, VIII. 1908, 4 specimens ; found under bark of partly decayed stem of a Dracona (together with one Acritus daubani), Mare aux Cochons, IX. 1908, 5 specimens. Mahé : from a felled coconut-stem on Long Island, VII. 1908, 2 specimens. Praslin : Côtes d'Or Estate, XI. 1908, 2 specimens. Félicité : from forest, XII. 1908, 7 specimens. La Digue : taken in numbers in company with Acritus (Halacritus) algarum under seaweed on the sandy beach, 1892 (Alluaud).

* Bickhardt, in Junk and Schenkling's Coleopt. Cat., Part 24, Histeridæ, 1910, p. 85, gives “Malacca” as the only locality of Bacanius ambiguus. I have before me a copy of Schmidt's paper, referred to above, in which he describes the species from the Seychelles, and I know of no subsequent record of its occurring elsewhere. Bickhardt's reference to Schmidt's description is otherwise correct. 
31. Bacanius inopinatus, Schmidt.

Bacanius inopinatus Schmidt, Ann. Soc. ent. France, 1893, Bulletin, p. 102 ; Alluaud, Liste Coléopt., p. 110 ; Kolbe, Mitt. Zool. Mus. Berlin, v. 1910, p. 21.

9 specimens, determined by comparison with a cotype kindly lent by Monsieur Alluaud.

Wings : examined in 1 specimen, fully developed, twice as long as the elytron.

Loc. Seychelles. Mahé: Cascade Estate, 800 feet or over, 1908-9; 1892 (Alluaud).

32. Bacanius atomarius, Sharp.

Bacanius atomarius Sharp, Trans. R. Dublin Soc., iii. 1885, p. 128 ; Scott, Fauna Hawaiiensis, iii. p. 510, Pl. 15, fig. 37, 1908.

Two specimens from the Seychelles are smaller than the Hawaiian examples, but after close comparison of both upper and under surfaces, side by side under the microscope, I am unable to find any distinguishing characters.

Loc. Seychelles. Mahé : Cascade Estate, 800 feet or over, 2 specimens. Hawaiian Islands (Oahu).

Acritus, Leconte.

Subgenus Halicritus Schmidt, Bull. Soc. ent. France, 1893, p. 103.

This subgenus is distinguished from Aletes and Acritus s. str. by the mesosternum being produced forward into a blunt point, and by the anterior tibiæ being dilated, emarginate at the extremity, and furnished with short spines along their outer edge. In the specimens before me (Halacritus algarum) there is a small visible scutellum, as in Acritus s. str. Also the diverging striæ on the metasternum become obsolete behind : they diverge rather widely, and then end blindly without curving at all : under a very high power there can be faintly seen a trace of a stria running down from the anterior corner of the metasternum to meet the diverging stria, but the two do not unite, and their course is such that, even if they did, they would form an angular or V-shaped stria, instead of the normal stria curving gradually round behind the middle coxa. Moreover, the striæ on the 1st abdominal segment, although they curve normally, appear to become obsolete and not to reach the side edge of the segment. A somewhat analogous condition is seen in the Hawaiian Acritus (Aletes) subrotundus (Fauna Hawaiiensis, iii. pp. 533-4, Pl. 15, fig. 33): in this, however, the striæ on both metasternum and 1st abdominal segment diverge very little and become obliterated behind after a very short course : this species belongs to a different subgenus and differs entirely from Halacritus in other ways. This character of the diverging striæ in Halacritus appears not to have been noted by Schmidt.

The nature of the wings is discussed below, under Halacritus algarum.

33. Acritus (Halacritus) algarum, Schmidt (Plate 14, fig. 26).

Acritus (Halacritus) algarum Schmidt, Ann. Soc. ent. France, 1893, Bulletin, p. 103 ; Alluaud, Liste Coléopt., p. 111 ; Kolbe, Mitt. Zool. Mus. Berlin, v. 1910, p. 22. 
The specimens before me consist of 18 from Mahé, 4 from Ceylon (named and given by Mr George Lewis), and 8 from Perim Island. Many of the Seychelles specimens are much larger and darker than the others. Those from Perim are especially small and some of them light in colour; but I have seen no characters indicating the presence of more than one species.

Wings: examined in 5 specimens from Mahé, 2 from Ceylon and 2 from Perim; in all these found to be reduced to minute vestiges, scarcely more than $\frac{1}{3}$ the length of the elytron. Micrometer measurements of wing- and elytron-lengths have been made in 2 Perim specimens, 2 Ceylon specimens, and 2 Seychelles specimens. Allowance must be made for error due to crumpling of the wing, \&c. The size of the organs of course varies with that of the individual. In the Perim specimens the wing is $0.19 \mathrm{~mm}$., the elytron $0.51 \mathrm{~mm}$. long: in a large Seychelles specimen, wing $0.23 \mathrm{~mm}$, elytron $0.6 \mathrm{~mm}$. The ratios between wing-length and elytron-length are $9: 26$ in the Perim specimens, 10:27 in the Ceylon and one of the Seychelles specimens, 11:29 in the other Seychelles specimen. Relative sizes of wing and elytron are shown in Pl. 14, fig. 26.

Reduced wings have also been found in Acritus (Aletes) longipes Sharp and its var. haleakalo Scott and in Acritus (AEletes) subalatus Scott, all from the Hawaiian Islands (see Fauna Hawaiiensis, iii. pp. 529, 530, and Pl. 15, figs. 25, 26).

Loc. Seychelles. Mahé: Long Island, from seaweed on beach, VII. 1908, 8 specimens; Anonyme Island, from seaweed, I. 1909, 10 specimens. La Digue and Marie Anne Islands, under seaweed, 1892 (Alluaud). Ceylon. Perim Island, Red Sea (J. J. Walker, voyage of H.M.S. "Penguin"; specimens in British Museum).

Subgenus Aletes, Horn, Proc. Am. Phil. Soc., xiii. 1873, p. 356.

Apart from Acritus (Halacritus) algarum, no member of the genus Acritus was previously known from the Seychelles. 3 species of the subgenus Aletes have now been found there, and are described below. Each is represented by 3 specimens, and all were found in the mountain-forests. All 3 species are minute forms, small even for the genus Acritus. The complete absence of a visible scutellum is the only character separating Aletes from subgenus Acritus s. str. According to Bickhardt's Catalogue of Histeridæ, 1910, no Aletes is recorded from Madagascar or S. Asia: no member of the whole genus Acritus is known from continental Africa: and the only two species known from Madagascar (Acritus alluaudi Schmidt and madagascariensis Schmidt, both of which I have seen through the kindness of Monsieur Alluaud) belong to the subgenus Acritus s. str. It may be noted that of 33 species of Acritus known from the Hawaiian Islands, 32 are AEletes and only 1 belongs to Acritus s. str. (see Fauna Hawaiiensis, iii. p. $514, \& c$.$) .$

34. Acritus (Aletes) daubani, sp. nov. (Plate 14, figs. 27, 28).

Ovalis, convexus, nitidus, ferrugineo-piceus, antennis pedibusque fusco-testaceis ; capite rare tenuissime punctulato; prothorace haud dense punctato, ante basin in medio 
lineâ transversâ crenulato-punctatâa parum arcuatâ, spatio inter hanc lineam et basin impunctato; elytris tenuiter haud dense punctatis; pygidio fere impunctato; prosterno inter strias circa dimidio longiore quam basi lato, striis antice divergentibus; mesosterno striâ marginali integrâ; lineâ transversâ punctorum elongatorum inter meso- et metasternum; metasterno in medio fere impunctato, ad latera sat fortiter haud dense punctato; segmento primo abdominis fere impunctato. Long. corp. $\frac{3}{4} \mathrm{~mm}$.

Rather narrowly oval, moderately convex, shining, pitchy-ferruginous with legs and antennæ paler. Head appearing impunctate, but under a high power a few very fine punctures are visible; no suture between frons and clypeus can be seen. The punctures on the prothorax are spaced out, separated usually by about twice their own diameter: in front of the base in the middle is a slightly arcuate crenate-punctate line, the space between it and the base being impunctate and not impressed; this line is not continued laterally to the posterior angles of the thorax. The elytral punctures are slightly less strong than those on the thorax, shallow and spaced out, so that except under a high power the elytra sometimes appear impunctate. I have had difficulty in satisfactorily making out the pygidial punctuation: the propygidium appears to be excessively finely punctulate, the pygidium almost impunctate. The prosternum ( $\mathrm{Pl}$. 14, fig. 28) between the striæ is about $1 \frac{1}{2}$ times as long as its breadth at the base; the striæe are very slightly nearer together in the middle than at the base, in front they diverge rather widely. Mesosternum ( $\mathrm{Pl}$. 14, fig. 28) with marginal stria entire, with the surface bearing a few excessively fine punctures only visible under a high power: separated from the metasternum by a chain of strong longitudinally-elongated depressions. Metasternum almost impunctate in the middle, rather strongly but not closely punctate at the sides. First abdominal segment almost impunctate, with a few punctures visible under a high power.

Characterised by its rather narrowly oval and convex form, numerous but not dense punctures, the presence of the arcuate punctate line at the base of the thorax, and of the transverse series of elongate punctures between meso- and metasternum.

This species is dedicated to Monsieur E. Dauban, owner of the island of Silhouette, in which all 3 specimens were found.

Loc. Seychelles. Silhouette: found, together with many Bacanius ambiguus, under bark of a felled dicotyledonous tree among coconut-plantations near coast, Pointe Étienne, 17. IX. 1908, 2 specimens; found under bark of partly decayed stem of a Draccena, together with several Bacanius ambiguus, in forest near Mare aux Cochons, IX. 1908, 1 specimen.

35. Acritus (Aletes) davidsoni, sp. nov. (Plate 14, figs. 29, 30).

Sat late ovalis, parum depressus, nitidus, piceo-ferrugineus, antennis pedibusque dilutioribus; capite subtilissime haud dense punctulato; prothorace elytrisque dense striolato-punctatis, striolis ad mediam basin prothoracis et ad angulos internos basales elytrorum convergentibus; prothorace serie basali punctorum munito; pygidio dense subtiliter striolato-punctulato, striolis transversis; prosterno inter strias subtilissime punctulato, parum longiore quam basi lato, antice et postice fere wque lato, in medio 
parum angustiore; mesosterno striâ marginali in medio interruptâ; lineâ inter meso- et metasternum tenui, haud punctatâ; meso- et metasterno et parte anteriore segmenti abdominalis primi dense sat fortiter striolato-punctatis. Long. corp. $\frac{5}{6} \mathrm{~mm}$.

Form rather broadly oval and a little depressed; colour reddish-pitchy. I have been unable to see any suture between clypeus and frons. 'The thorax and elytra are fairly closely punctured, the punctures being drawn out before and behind into extremely fine scratches, producing a dense striolation: the striolæ curve and bend slightly, and their courses follow different directions in different parts; but there is a general convergence towards the middle of the base of the thorax and towards the inner basal angles of the elytra, towards which points also the actual punctures become stronger and closer together; towards the shoulders of the elytra the punctures become obsolete, but the striolæ are still present. In addition, the prothorax bears a series of punctures closely following the basal margin. Even on the head traces of this striolation are just visible. The propygidium and pygidium are also closely and finely striolate-punctate, the general direction of the striolæ being transverse.

The prosternum ( $\mathrm{Pl}$. 14, fig. 30) between the striæ is a little longer than broad at the base, narrowest in the middle, with front and hind margins of nearly equal breadth. The mesosternum (Pl. 14, fig. 30) has the marginal stria interrupted in the middle; just within this stria on either side is a series of very fine punctures. The division between meso- and metasternum is visible as a fine line, but without any special sculpture. Mesoand metasternum strongly punctured, the punctures closer in the middle of the metasternum than at the sides, drawn out into short striolæ longitudinal in direction. First abdominal segment with sculpture of a similar nature, but much sparser, almost absent towards the posterior margin. Even the prosternum bears a few very fine punctures and a minute trace of striolation.

The above description is made from two specimens. There is a third which resembles them in form, structure, and colour, but differs in being totally devoid of the characteristic striolation. The punctures are present, and distributed in the same manner, but are not drawn out into striolæ at all. I am inclined to think the difference may be sexual, but paucity of material prevents my attempting to prove this by dissection.

This species is dedicated to His Excellency Mr W. E. Davidson, Governor of the Seychelles at the time of my visit.

Loc. Seychelles. Silhouette : high damp forest near Mont Pot-à-eau, ca. 1500 feet, VIII. 1908, two specimens (one of the striolate specimens, and that devoid of striolation). Mahé : from near Morne Blanc, X. 1908, one specimen.

36. Acritus (Aletes) fryeri, sp. nov. (Plate 14, figs. 31, 32).

Minutissimus, oblongo-ovalis, depressus, ferrugineus, antennis pedibusque dilutioribus ; capite impunctato; prothorace elytrisque dense subtiliter striolato-punctatis, punctis subtilissimis, in basi prothoracis parum fortioribus; prosterno inter strias in medio parum angustiore quam in basi, striis antice parum divergentibus; lineâ inter meso- et meta- 
sternum in medio punctis aliquibus majoribus; meso- et metasterno et segmento abdominali primo subtiliter striolato-punctulatis. Long. corp. $\frac{2}{3} \mathrm{~mm}$.

Form oblong-oval and depressed. Head impunctate, without visible suture between frons and clypeus. Thorax and elytra covered with a dense fine striolation. The punctures themselves are extremely fine and some way apart, but the fine striolæ into which they are drawn out before and behind form a dense sculpture : towards the base of the thorax the punctures are a little stronger, and they form a somewhat irregular series, not very close, along the actual base. The general direction of the striolæ is much more longitudinal than in the preceding species: there is no general convergence towards middle of base of thorax or towards inner basal angles of elytra: at the apex of the elytra the inner striolæ curve inwards towards the sutural angle. Sculpture of the pygidium not satisfactorily made out; it appears to have extremely fine transverse striolations, but to be smooth and unsculptured at the apex.

Prosternum (Pl. 14, fig. 32) between the strix a little more than $1 \frac{1}{2}$ times as long as broad at the base, slightly narrower in the middle than at the base, with striæ diverging somewhat in front; surface slightly convex with a few fine striolations. It is not possible to see whether the mesosternal marginal stria is entire or not, since its median portion is hidden under the base of the prosternum. The division between mesoand metasternum is visible: it has no definite transverse series of punctures, but in its median part there are about six rather larger punctures placed transversely, not very close together. Meso- and metasterna and 1st abdominal segment finely striolatepunctulate, the striolæ being short and generally longitudinal in direction, and the punctures very fine; this sculpture becomes obsolete at the hind margin of the 1st abdominal segment.

Distinguished from the preceding by its much smaller size, oblong and flattened form, by its very fine punctures, the different arrangement of the striolæ, \&c.

This species is dedicated to $\mathrm{Mr}$ J. C. F. Fryer.

Loc. Seychelles. Mahé: Cascade Estate, over 800 feet, 1909, 1 specimen; Mare aux Cochons district, 1500 feet or over, 1909, 1 specimen. Praslin : Côtes d'Or Estate, 1908, 1 specimen.

\section{SAPRInus, Erichsan.}

\section{Subgenus Saprinus, s. str.}

\section{Saprinus erichsoni, Marseul.}

Saprinus erichsoni Marseul, Ann. Soc. ent. France, sér. 3, iii. 1855, p. 363, Pl. 16, fig. 8; Alluaud, Liste Coléopt., p. 110 ; Kolbe, Mitt. Zool. Mus. Berlin, v. 1910, p. 21.

Not obtained by the Percy Sladen Trust Expedition. The single specimen found by Alluaud was stated by J. Schmidt (Bull. Soc. ent. France, 1893, p. 101) to be perfectly identical with specimens from Madagascar.

Loc. Seychelles: Mahé, 1892 (Alluaud). Madagascar. 
Subgenus Hypocaccus Thomson; Lewis, Ann. Mag. Nat. Hist., ser. 7, iv. pp. 1-3, figs. 6,7 .

38. Saprinus (Hypocaccus) disjunctus, Marseul.

Saprinus disjunctus Marseul, Ann. Soc. ent. France, sér. 3, iii. 1855, p. 731, Pl. 20, fig. 163; Alluaud, Liste Coléopt., p. 109.

22 specimens, determined by comparison with a named specimen from Madagascar (kindly given by $\mathrm{Mr}$ George Lewis).

Loc. Cargados Carajos Islands: Establishment Island, 28. VIII. 1905, common in dead birds. Madagascar. Comoros (teste Alluaud).

39. Saprinus (Hypocaccus) apricarius, Erichson.

Saprinus apricarius Erichson, in Klug, Jahrb. Ins., i. 1834, p. 194.

4 specimens from Seychelles and 1 from Providence: specimens submitted to $\mathrm{Mr}$ George Lewis, by whom the determination was confirmed. In all the specimens the elytral punctuation is reduced in area, the punctures not extending forward at all along the interstices between the 2nd, 3rd, and 4th dorsal striæ: the species is very variable in

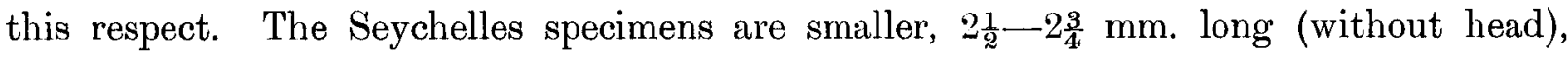
and have the elytral punctures stronger; they have two irregular rows of strong: punctures along the base of the thorax; they fairly closely resemble some South African specimens in the British Museum.

The specimen from Providence is larger, about $3 \frac{1}{2} \mathrm{~mm}$. long (without head); it has the punctures on thorax and elytra much finer, those along the base of the thorax being reduced to a single series of fine punctures: in punctuation it somewhat resembles some specimens from Zanzibar in the British Museum, but these are not so large.

Loc. Seychelles: Bird Island, VII. 1908 (Fryer). Providence: Cerf Island, on rotten fish, 3. X. 1905. South Europe, Africa, Southern Asia and Malay Archipelago.

\section{DESCRIPTION OF PLATE 14}

Fig. 1. Paromicrus carinatus, gen. et sp. nov., $\times 30$.

Fig. 2. " "

Fig. 3. " " labrum.

Fig. 4. " atomus, labrum.

Fig. 5. " carinatus, mandible (perhaps slightly distorted).

Fig. 6. " " maxilla.

Fig. $7 . \quad$, $\quad$ labium.

Fig. 8. ", " middle tibia and tarsus.

Fig. 9. " " $\quad$ elevated part of mesosternum: $a$, ventral view; $b$, lateral view;

S, meso-metasternal suture; $\mathbf{C}$, middle coxal cavity.

Fig. 10. Paromicrus thomasseti, elevated part of mesosternum, ventral view.

Fig. 11. , atomus, 
Percy Sladen Trust Expedition.

(SCOTT)

Trans. Linn. Soc. Ser Z Zool Vol XVI Pl.14.
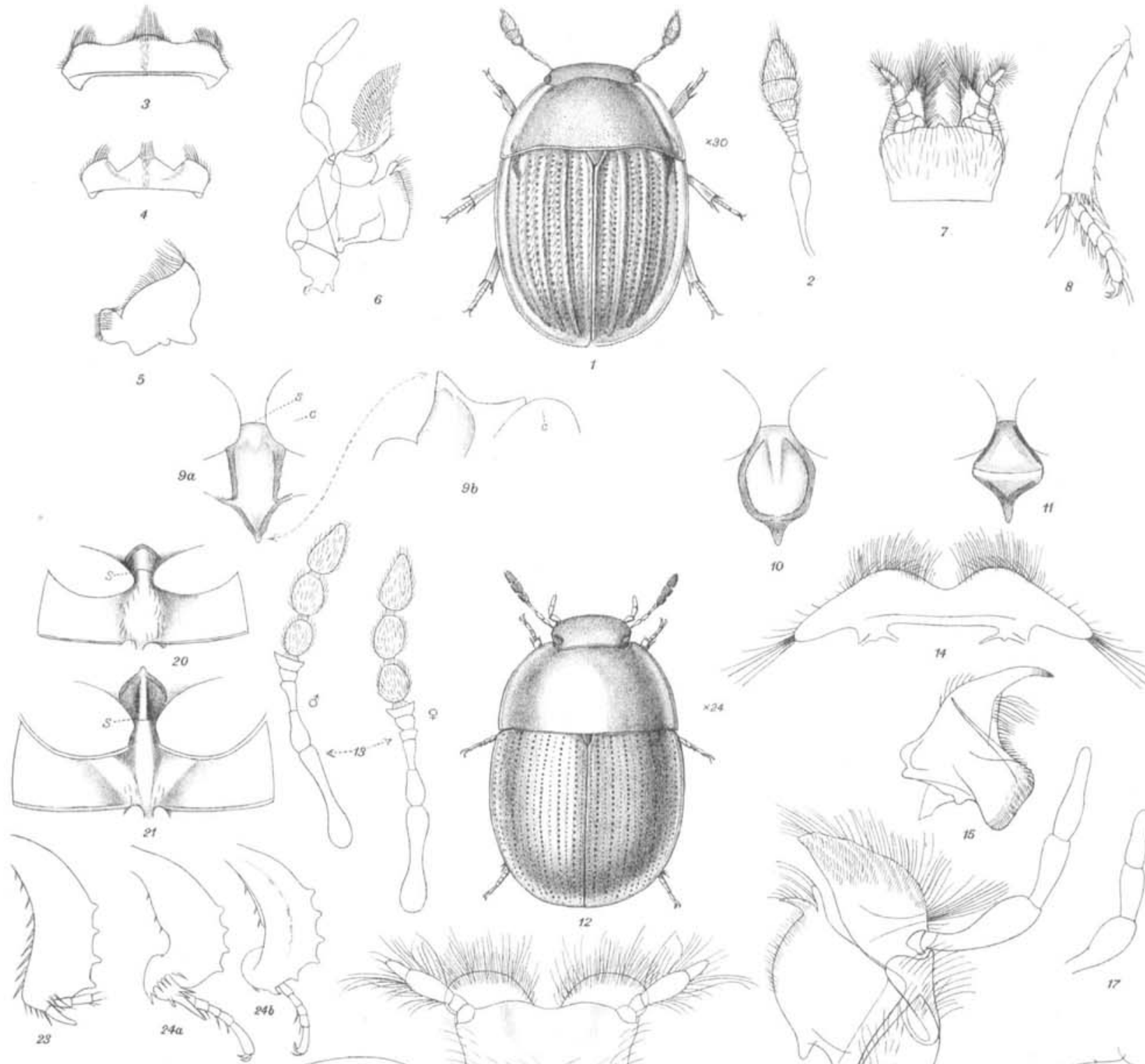

10
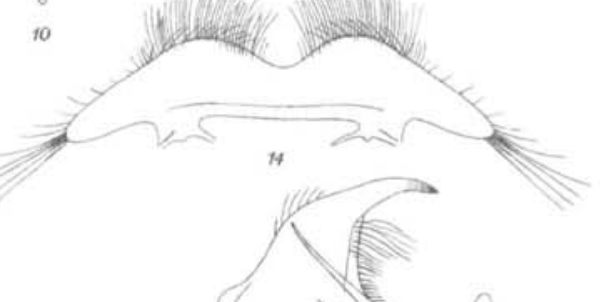

(5)

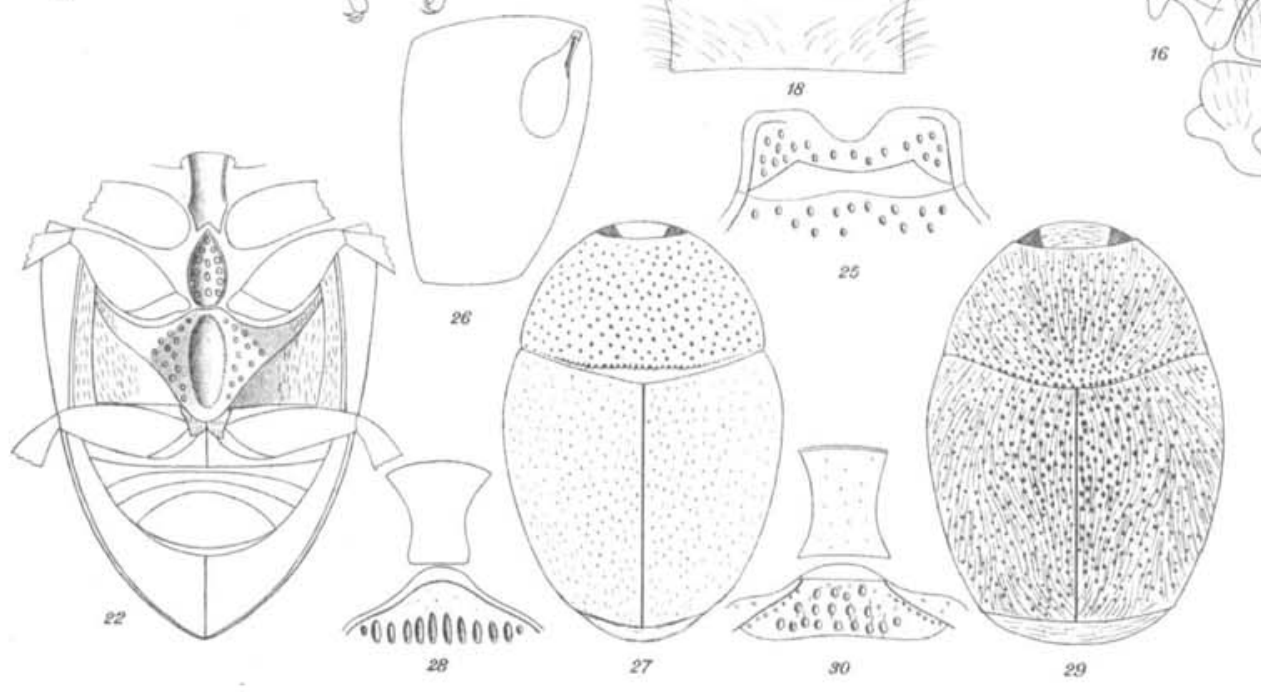

H.Scott \& E.Wilson del. 
Fig. 12. Bourdonnaisia mahensis, gen. et sp. nov., $\delta, \times 24$.

Fig. 13.

Fig. 14.

Fig. 1 อ.

Fig. 16.

Fig. 17.

Fig. 18.

Fig. 19.

Fig. 20. antenna $\delta$ and $q$.

labrum.

" mandible.

silhouette, maxilla.

mahensis, last 3 joints of maxillary palp.

labium.

" hind tibia and tarsus.

$"$ elevated part of mesosternum, and metasternum; middle coxw

removed: $\mathbf{S}$, meso-metasternal suture.

Fig. 21. Bourdonnaisia silhouette, same parts as in preceding figure.

Fig. 22. Paroosternum degayanum, gen. et sp. nov.; under-surface, showing pro-, meso-, and metasterna.

Fig. 23. Paromalus gardineri, sp. nov., $\delta$, front tibia, seen from in front.

Fig. 24. " calciger, sp. nov., $\sigma^{\nearrow}$, front tibia: $a$, seen from in front; $b$, seen from behind. Fig. 25. " " $\delta$, mesosternum.

Fig. 26. Acritus (Halacritus) algarum Schmidt: outline of elytron and wing to same scale.

Fig. 27. ", (Aletes) daubani, sp. nov.

Fig. 28. " " " pro- and mesosterna.

Fig. 29. " $\quad$ davidsoni, sp. nov.

Fig. 30. ", " " pro- and mesosterna.

Fig. 31. " " fryeri, sp. nov.

Fig. 32. " " " prosternum. 